\title{
The short-legged Andean cosmetids revisited: the genus Libitia Simon, 1879 with description of two new species (Opiliones, Cosmetidae)
}

\author{
Miguel MEDRANO ${ }^{1, *}$, Ludson Neves de ÁZARA ${ }^{2}$ \& Adriano Brilhante KURY ${ }^{3}$ \\ ${ }^{1,2,3}$ Laboratório de Aracnologia, Departamento de Invertebrados, Museu Nacional/UFRJ, \\ Quinta da Boa Vista, São Cristóvão, 20.940-040, Rio de Janeiro - RJ, Brazil. \\ ${ }^{1}$ Corresponding author: miangelmed@gmail.com \\ 2ludsonazara@yahoo.com.br \\ 3adrianok@gmail.com \\ ${ }^{1}$ urn:1sid:zoobank.org:author:C7F7D4CF-F9B2-44AF-9F03-86278ADBD4F2 \\ ${ }^{2}$ urn:1sid:zoobank.org:author:4ECF193A-694C-43CE-8EE6-F197EDDA4414 \\ ${ }^{3}$ urn:lsid:zoobank.org:author:60FAE1F8-87F7-4A5F-BE78-BEB25BC4F898
}

\begin{abstract}
The old genus Libitia Simon, 1879 of small Andean harvestmen is revisited. The monotypic genus Libitiella Roewer, 1947 is herein considered a junior subjective synonym of Libitia. Accordingly, Libitiella bipunctata (Sørensen, 1932) is restored to the combination Libitia bipunctata. The species Libitia cordata and Libitia bipunctata comb. nov. are redescribed and the new species Libitia gandalf sp. nov. and Libitia iguaque sp. nov. are herein described from Cordillera Oriental of Colombian Andes (Chingaza Natural Park and Iguaque Natural Park, respectively). The species Gonyleptes multimaculatus Wood 1869 , currently under the synonymy of L. cordata, is revalidated and transferred to Paecilaemella Roewer, 1925 forming Paecilaemella multimaculata comb. nov., and the species Cynorta itacoaiensis $\mathrm{H}$. Soares, 1970 is herein considered a junior subjective synonym of it. In addition, the second current species of the genus, Libitia fusca (Simon, 1879), is transferred to Metalibitia. Libitia is diagnosed based in genital and external morphology, an identification key of the four species and distribution maps are offered.
\end{abstract}

Keywords. Gonyleptoidea, Neotropics, Andes, Metalibitia, Paecilaemella.

Medrano M., Ázara L.N. de \& Kury A.B. 2020. The short-legged Andean cosmetids revisited: the genus Libitia Simon, 1879 with description of two new species (Opiliones, Cosmetidae). European Journal of Taxonomy 634: 1-25. https://doi.org/10.5852/ejt.2020.634

\section{Introduction}

The Northern Andes have a high topographic complexity, recognized as a biodiversity hotspot (Myers et al. 2000). Opilionological fauna is common and abundant in Andean realms but its taxonomy is still poorly understood and its diversity is underestimated. Cosmetid harvestmen of Andes have received better attention in the last few years in Bolivia (Monteiro \& Pinto-da-Rocha 2015) and Colombia (García \& Kury 2017; Medrano \& Kury 2017). Venezuelan species were much favored earlier thanks 
to the bulky taxonomic work of the arachnologist Manuel Ángel González-Sponga (1992, 1996, 1998a, 1998b) and more recently by the revision of the genus Neocynorta Roewer, 1915 in the cordillera of Mérida (Medrano et al. 2019).

\section{Historical background}

An early expedition to Nueva Granada by the French naturalist Justin Goudot (who was based in Bogotá) allowed Gervais (1844) to examine and describe some species inhabiting the territory currently corresponding to Colombia. One of those specimens was described as Cosmetus cordatus Gervais, 1844, characterized in a brief description by having a singular heart-shaped spot ("coeur de carte à jouer") on the dorsum. Some years later, Simon (1879: 216) created the genus Libitia for cosmetids with short legs, unarmed abdomen and five segments in legs I, III and IV, including C. cordatus and the new species Libitia fusca Simon, 1879. He also mentioned the singularly inflated basitarsomeres of posterior legs in L. cordata and lacking in L. fusca.

Metalibitia Roewer, 1912 and Paralibitia Roewer, 1912, genera with short legs and flat scutum, were synonymized under Libitia by Sørensen (1932: 411) which in turn was divided in two subgenera: Messa and Libitia. The former subgenus is unavailable because it was published after 1930 without designation of a type-species from among the two originally included (ICZN Art. 13.3) and, moreover, it would be invalid as a junior homonym of Messa Leach, 1817 (Hymenoptera). In the latter, Sørensen included L. cordata and the new species L. bipunctata, recognizing the tarsal incrassation of basitarsomeres of posterior legs as diagnostic character of the subgenus. He did not include Libitia fusca in the genus.

Mello-Leitão (1933: 109) promoted the subgenus Libitia (including both species proposed by Sørensen) to genus and dismembered the second subgenus Messa into four genera: Paralibitia, Metalibitia, Messa Mello-Leitão 1933 and Paramessa Mello-Leitão 1933. Although the similarity between L. cordata and L. bipunctata was remarkable and already noticed by Sørensen (1932), the difference in tarsal counts was enough for Roewer (1947: 8) to create a separate genus for L. bipunctata: the monotypic Libitiella Roewer, 1947.

Separately, in 1869, Wood described Gonyleptes multimaculatus from "Napo and Maravon", based on a single specimen lacking pedipalps and "maxillae". Its description includes the presence of a transverse yellow stripe just posterior to the ocularium and minute whitish spots in dorsal scutum and coxa IV. Although, the lack of pedipalps made difficult identification at family level, Butler (1873: 115) recognized it as a cosmetid. Nonetheless, in a lapsus of overconfidence, he established the synonym with $C$. cordatus without any detailed explanation, but probably based on the vague similarity of the white spot on the anterior scutum of both species. The name was later combined with the genus Cranaus by Simon (1879: 216) but this combination was not followed by any other author and it remains today a junior synonym of $L$. cordata.

Libitia currently contains two species described in later $19^{\text {th }}$ century: L. cordata and L. fusca from the vague locations "Colombia" and "South America", respectively. Recently, Medrano \& Kury (2018) recovered the genus within a group with two other Andean genera of flat cosmetids: Eulibitia Roewer, 1912 and Ambatoiella Mello-Leitão, 1943, but the status of its species were not studied.

The aim of this work is to review the genus Libitia, which are small cosmetid harvestmen with short legs and a flat unarmed dorsal scutum. We hereby recognize four valid species in the genus, among them two new species from Meta and Boyacá Departments in the highlands of Colombia. A key for the identification and a map of the known distribution of species are provided. Additional nomenclatural acts are proposed for names mistakenly associated with Libitia. 


\section{Material and methods}

Descriptions of colors use the standard names of the 267 Color Centroids of the NBS/IBCC Color System (http://people.csail.mit.edu/jaffer/Color/Dictionaries\#nbs-iscc) as described in Kury \& Orrico (2006). Scanning Electron Microscopy was carried out with JEOL JSM-6390LV at the Center for Scanning Electron Microscopy of Museu Nacional/UFRJ and at Rudolf Barth Electron Microscopy Platform of the Oswaldo Cruz Institute / FIOCRUZ. All measurements are in millimeters unless otherwise indicated.

\section{Repositories}

$\mathrm{BMNH}=$ The Natural History Museum, London, UK

$\mathrm{IAvH}=$ Instituto Alexander von Humboldt, Villa de Leyva, Colombia

ICN = Instituto de Ciencias Naturales, Universidad Nacional de Colombia, Bogotá, Colombia

MNHN $=$ Muséum national d'histoire naturelle, Paris, France

MNRJ = Museu Nacional, Rio de Janeiro, Brazil

MPUJ = Museo Javeriano de Historia Natural "Lorenzo Uribe, S.J.", Bogotá, Colombia

$\mathrm{ZMG}=$ Zoologisches Museum of the Georg-August-Universität, Göttingen, Germany

\section{Other abbreviations}

$\mathrm{AL}=$ abdominal scutum length
$\mathrm{AW}=$ abdominal scutum width
$\mathrm{CL}=$ carapace length
$\mathrm{CW}=$ carapace width
$\mathrm{Fe}=$ femur
$\mathrm{Ti}=$ tibia

Tarsal formula: numbers of tarsomeres in tarsus I to IV, when an individual count is given, order is from left to right side (figures in parentheses denote number of tarsomeres only in the distitarsi I-II).

Terminology for outline of dorsal scutum follows Kury \& Medrano (2016). The terminology of the macrosetae of the penis ventral plate follows Kury \& Villarreal (2015). The species descriptions do not repeat the generic characteristics. The term coda, here used, refers to the posterior part of the dorsal scutum, recognizable as the part with parallel straight sides, posterior to the main slope-change caused by the widened convex laterals. This term was first used and defined by Kury (2012).

The illustrations were made using a stereo microscope with a camera lucida and digitalized using the software Inkscape ver. 0.92. Photographs were taken with a Sony Cybershot DSC-V1 camera attached to the stereo microscope. The software package CombineZP by Alan Hadley, was used to create composite images with extended depth of field, through combination of several images taken at different focal planes. The resulting images were edited with Adobe Photoshop CS5. The plates were prepared in CorelDraw X7 for photographs.

All type material of Opiliones in the Zoologisches Museum of the Georg-August-Universität in Göttingen has been destroyed, according to information from the curator Dr Gert Tröster (June 28, 2011). All types designated here and the examined material were lost in the fire of September $2^{\text {nd }} 2018$ along with the bulk of the arachnological collection of MNRJ (Kury et al. 2018), except for material of L. bipunctata (ICN-AO 470, ICN-AO 1204 and ICN-AO 771) and a female paratype of L. iguaque sp. nov. (MPUJENT 1432). There is no formal impediment according to the ICZN rules (ICZN Code: Art. 72.5.6 and 73.1.4) to describe a species whose holotype was lost before its publication (see Krell \& Marshall 2017) for a discussion on this topic). Type material of $L$. gandalf sp. nov. was destroyed before illustration 
of chelicerae and pedipalps; nevertheless, those parts do not possess significant diagnostic features for identification, thus the non-description of these parts does not compromise the validity of the species.

\title{
Results
}

\author{
Class Arachnida Lamarck, 1801 \\ Order Opiliones Sundevall, 1833 \\ Suborder Laniatores Thorell, 1876 \\ Family Cosmetidae C.L. Koch, 1839 \\ Subfamily Cosmetinae C.L. Koch, 1839 \\ Genus Libitia Simon, 1879
}

Libitia Simon, 1879: 216 [type species: Cosmetus cordatus Gervais, 1844, by subsequent designation of Roewer (1912)]

Libitiella Roewer, 1947: 8 [type species: Libitia bipunctata Sørensen, 1932, by original designation]. syn. nov.

Libitia - Simon 1880: 103 - Roewer 1912: 11; 1923: 293. — Mello-Leitão 1923: 108; 1926: 331; 1932: 53; 1933: 105, 109; 1935: 113. — Kästner 1937: 389. — Kury 2003: 65 (revalidated) [junior subjective synonym of Vonones Simon, 1879 by Goodnight \& Goodnight (1953: 59)].

Libitia (Libitia) - Sørensen in Henriksen 1932: 417.

non Libita [subsequent incorrect spelling] - Roewer 1928: 552.

\section{Etymology}

Obscure, it sounds to us as a Roman woman's name. Gender feminine.

\section{Diagnosis}

Can be differentiated in having shorter legs (femur IV shorter than the total length of the dorsal scutum) contrasting with other short-legged cosmetids as Rhaucus Simon, 1879, Neocynorta or Eulibitia (its femur IV is longer than dorsal scutum length) (Fig. 1B, E-F). Outline of dorsal scutum alpha-type with faint marked constrictions forming a parallel coda in males and divergent coda in females contrasting with Ambatoiella that has well-marked constrictions (Figs 2, 6). Can be separated from other genera by having cheliceral sockets (invaginations in the anterior margin of the carapace where the basichelicerites fit) shallow, with well-marked lateral quadrangular projections (triangular in Eulibitia, rounded in Rhaucus, bifid in Metalibitia) (Figs 2, 6). Posterior margin of DS without yellow stripe (transversal stripe in Eulibitia and some Rhaucus species) (Fig. 1A-D). Basitarsomeres I, III and IV remarkably enlarged in males (Figs 1B, 5B, D, 9C-D). Penis with an elongate wattle in stylus forming distally two long serrate membranes and with a medial cleft (Fig. 5), without stylar barbs.

\section{Description}

Small and flat animals $(<4 \mathrm{~mm})$ with short legs (Fig. 1B). Outline of dorsal scutum alpha-type with symmetrical mid-bulge (Fig. 2).

Mesotergum flat and unarmed. Scutum with yellowish white blots as a 'ladder mask' over dark brown background (see Medrano \& Kury 2016, 2017), with intraspecific variation from absent (Fig. 2) to strongly filled invading the entire area I and II (Fig. 6) or part of carapace (Fig. 9A).

Coxa IV entirely visible in dorsal view, without groin warts (defined in Kury \& Barros, 2014) and small prodorsal distal apophysis. Femur III and IV curved and uniformly tuberculate (Fig. 1B). 
Penis (Fig. 4): ventral plate (VP) sub-rectangular with latero-apical borders protruding from the ventral plate, stylus with an incrassated wattle forming apically two long serrate membranes creating a medial cleft (Fig. 4D), without stylar barbs. VP laterally with two pairs of MS A, two pairs of MS C (sometimes asymmetrical with 3 MS C on one side, as in L. bipunctata and L. gandalf sp. nov.), two pairs of MS D (D1 three times longer than D2), and ventrally with two pairs of MS E and one pair MS B (Fig. 4C).

\section{Note}

As no diagnostic differences have been found among the penes of each of the four species, no specific descriptions are made.

\section{Included species}

Libitia cordata (Gervais, 1844), Libitia bipunctata Sørensen, 1932, Libitia gandalf sp. nov. and Libitia iguaque sp. nov.

\section{Geographic distribution}

Central part of Eastern Cordillera of Andes from 2600 to 3700 meters, in Cundinamarca, Boyacá and Meta departments of Colombia.

\section{Key to males of Libitia}

1. Pattern of blots invading carapace and area and occupying entirely area I of mesotergum (Fig. 9A, C, E) L. gandalf sp. nov.

- Pattern of blots restricted to mesotergum (Figs 2, 6, 11A-B) 2

2. Pattern of blots invading area I and part of II, forming an irregular heart-shape (Figs $5 \mathrm{~A}-\mathrm{B}, 6)$ )...... L. cordata (Gervais, 1844)

- Pattern of blots only in lateral margins of mesotergum forming the rails of a ladder not invading areas I or II, sometimes extremely reduced (Figs 2, 11A-B) 3

3. Coda shorter than mid-bulge (Fig. 11A); maximum width of dorsal scutum equal to maximum length (Fig. 11A); legs podomeres with same color of trochanter (Fig. 11B-F); three basitarsomeres in legs I and III; penis with MS D1 equally distanced from MS D2 and MS C2 (Fig. 12A-D)

L. iguaque sp. nov.

- Coda as long as mid-bulge (Fig. 1A); maximum width of dorsal scutum shorter than maximum length (Fig. 1A); legs podomeres darker than trochanter (Fig. 1B-F); two basitarsomeres in legs I and III; penis with MS D1 closer to MS C2 than MS D2 (Fig. 4)

L. bipunctata Sørensen, 1932 comb. rev.

Libitia bipunctata Sørensen, 1932 comb. rev. Figs $1-4,14$

Libitia (Libitia) bipunctata Sørensen in Henriksen, 1932: 417.

Libitia bipunctata - Mello-Leitão 1933: 109.

Libitiella bipunctata - Roewer 1947: 8, pl. 1, fig. 3.

\section{Diagnosis}

Can be distinguished from L. cordata and L. gandalf sp. nov. by having small white-yellowish blots restricted to the marginal scutal groves (or sulci) (rails, see Medrano \& Kury 2016) as dissociated 

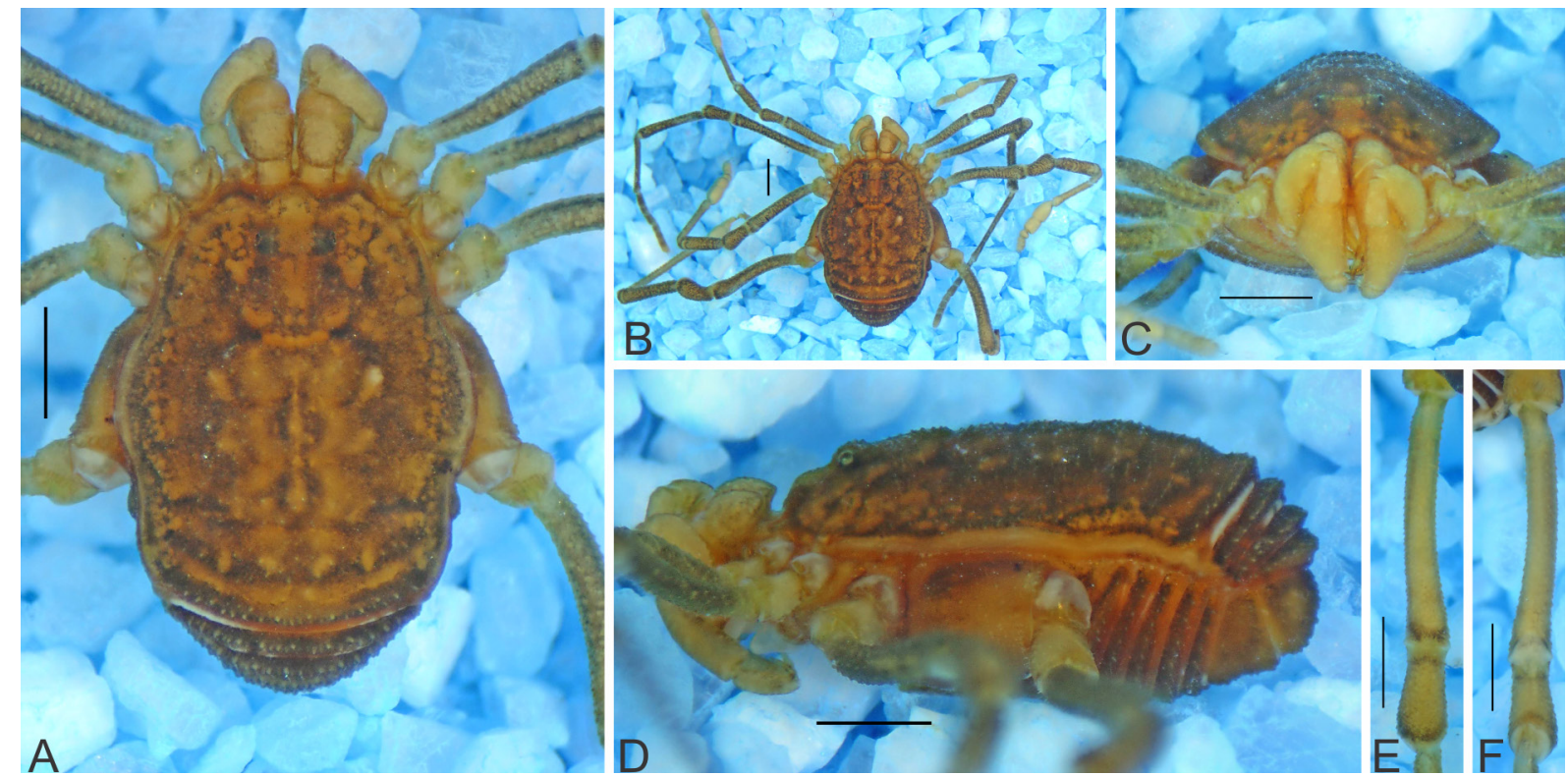

Fig. 1. Libitia bipunctata Sørensen, 1932, ô (ICN-AO 1040), habitus. A. Dorsal view. B. Dorsal view, panoramic. C. Frontal view. D. Lateral right view. E-F. Right femur IV, dorsal and ventral view, respectively. Scale bars $=1 \mathrm{~mm}$.
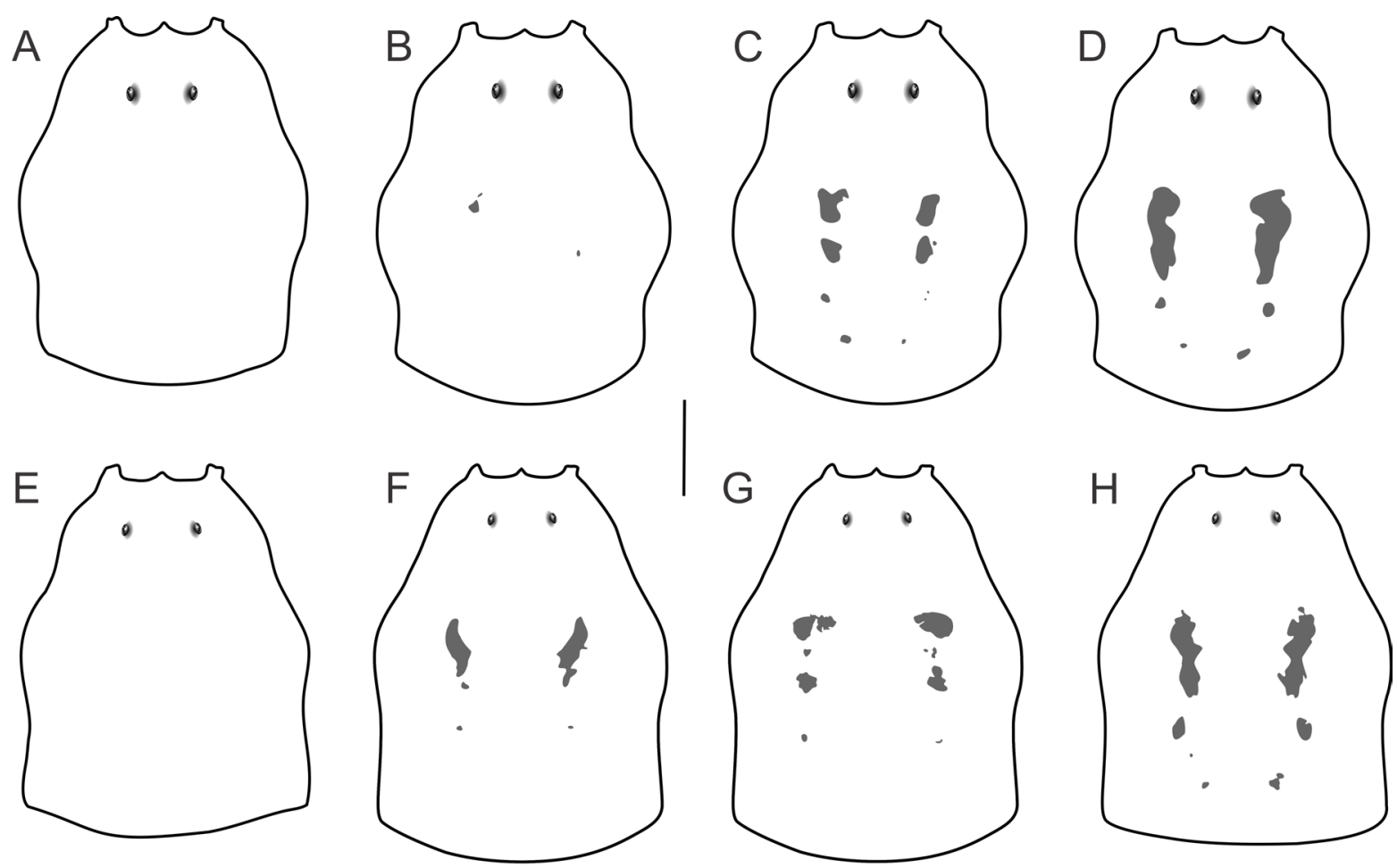

Fig. 2. Libitia bipunctata Sørensen, 1932, variation of spot pattern on dorsal scutum. A-D. $\widehat{\partial} \widehat{\delta}$. A. IAvH-I-67. B. ICN-AO 468. C. ICN-AO 419. D. IAvH-I-87. E-H. 우. E. IAvH-I-76. F-H. UNALAO 420. Scale bar $=1 \mathrm{~mm}$. 
pattern; from L. iguaque sp. nov. by having coda as long as mid-bulge and by possessing penis with MS D1 closer to MS C2 than MS D2.

\section{Etymology}

The name is derived from the Latin 'bipunctatus', meaning 'one who has two blots'.

\section{Material examined}

\section{Syntypes}

COLOMBIA - 2 우; Cundinamarca Department [originally mistakenly reported as "Venezuela"], without further locality data; BMNH $-3 \hat{\jmath} \widehat{\partial}, 2$ 우; between La Unión and Páramo de Chingaza [originally misspelled as "Chingusa"]; 1000-2400 m a.s.1.; ZMG.

\section{Other material}

COLOMBIA - Cundinamarca Department $-26 \widehat{\partial} \partial^{\lambda}, 17$ 우, 20 juvs; Bogotá, Cantera Soratama; 2800 m a.s.l.; A. Álvarez leg.; MPUJ ENT $11432 \bullet 1$ ô, 1 O ; Bogotá, Humedal La Conejera; $4.760671^{\circ} \mathrm{N}$, $74.106359^{\circ} \mathrm{W} ; 2600 \mathrm{~m}$ a.s.1.; Apr. 2000; ICN-AO 292 • 1 đo; Bogotá, Quebrada La Vieja; $4.649889^{\circ} \mathrm{N}$, $74.048065^{\circ}$ W; 2600 m a.s.1.; 12 Dec. 2010; O. Villarreal, D. Luna and M. Medrano leg.; ICN-AO 922

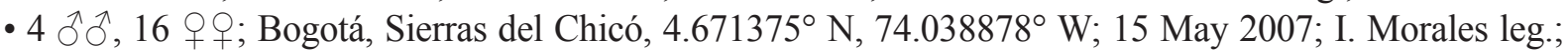
ICN-AO 470 • 10 o O; Bogotá, Usme, Parque Entrenubes, Cerro Juan Rey; $4.521586^{\circ} \mathrm{N}, 74.097581^{\circ} \mathrm{W}$; 2700 m a.s.l.; 23-25 May 2003; L. Benavides leg.; ICN-AO 420 • 1 ô, 14 o ; ; same collection data as for preceding; ICN-AO 419 • 1 đ; Choachí, Páramo Cruz Verde vía Bogotá-Choachí; $4.592793^{\circ} \mathrm{N}$,

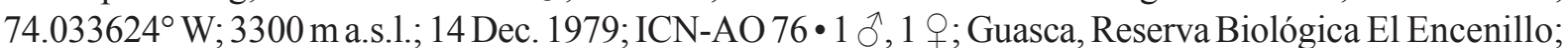

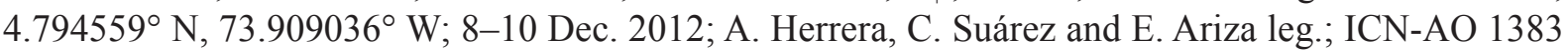
- 1 đ̃, 3 o क; Guasca, Reserva Biológica El Encenillo; 8-10 Dec. 2012; C. Suárez and E. Ariza leg.; necrotrampa; ICN-AO 1204 12 + ; La Calera, E.A.A.B. Club La Aguadora - Embalse de San Rafael; $4.706040^{\circ}$ N, 74.008119 W; 2700 m a.s.1.; Sep. 2010; P. Barriga and D. Tobar leg.; ICN-AO 472 • 5 ㅇ; same collection data as for preceding; ICN-AO $484 \cdot 1$ 万人; Parque Nacional Natural Chingaza, Alto de La Bandera; $4.719018^{\circ} \mathrm{N}, 73.820675^{\circ} \mathrm{W} ; 3660 \mathrm{~m}$ a.s.1.; IAvH-I-64 • 1 o ; same collection data as for preceding; IAvH-I-67 • 1 \% ; same collection data as for preceding; IAvH-I-76 1 O ; same collection

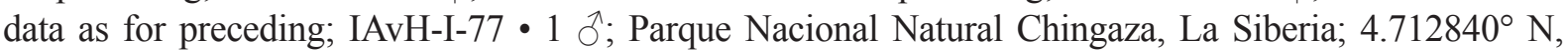

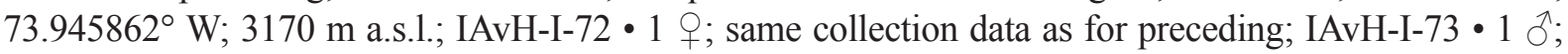
Parque Nacional Natural Chingaza, Vda. El Manzano, Reserva Forestal Río Blanco, Palacio Laguna Brava; $4.675665^{\circ} \mathrm{N}, 73.880396^{\circ} \mathrm{W} ; 2930 \mathrm{~m}$ a.s.l.; IAvH-I-87 • 1 क; Parque Nacional Natural Chingaza, Valle

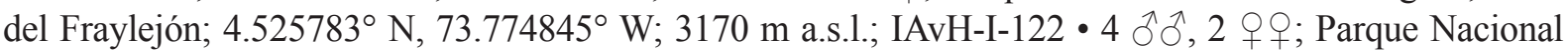
Natural Chingaza; $4.575^{\circ} \mathrm{N}, 73.853^{\circ} \mathrm{W}$; $2950 \mathrm{~m}$ a.s.1.; Y. Cifuentes leg.; ICN-AO $1437 \bullet 1$ ○; San Antonio del Tequendama, Los Tunos; $4.564730^{\circ} \mathrm{N}, 74.218390^{\circ} \mathrm{W} ; 2009$; ICN-AO $996 \bullet 1$ `े; Sibate, Alto de San Miguel; $4.450395^{\circ} \mathrm{N}, 74.300759^{\circ} \mathrm{W} ; 2630 \mathrm{~m}$ a.s.1.; 1 Dec. 1979; I. de Arevaldo leg.; ICN-AO $78 \bullet 1$ đ,

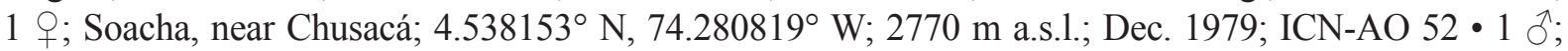
Zipaquirá, Vereda Ventalarga, Represa Pantano Redondo; 5.042453 ${ }^{\circ} \mathrm{N}, 74.036160^{\circ} \mathrm{W} ; 3000 \mathrm{~m}$ a.s.l.; 27 Apr. 2013; E. Florez et al. leg.; ICN-AO 468.

\section{Redescription}

\section{Male (ICN 419)}

Measurements. $\mathrm{CL}=1.4, \mathrm{AL}=2.7, \mathrm{CW}=2.4, \mathrm{AW}=3.3, \mathrm{IOD}=0.6, \mathrm{Fe} \mathrm{I}=1.7, \mathrm{Ti} \mathrm{I}=1.3, \mathrm{Fe} \mathrm{II}=2.9$, $\mathrm{Ti} \mathrm{II}=2$, Fe III $=2.5$, Ti III $=1.5, \mathrm{Fe} \mathrm{IV}=2.7$, Ti IV $=2.1$.

Dorsum (Fig. 1A-D). Dorsal scutum alpha-type, finely granular. Free tergites with rows of granules. Posterior margin of dorsal scutum convex. Small white-yellowish blots restricted to the marginal scutal groves, not invading the areas of mesotergum nor grooves medially. 
VENTER. Free sternites finely granular; coxae II-IV finely and uniformly granular; coxa I with longitudinal row of tubercles and smooth area corresponding to lace area of pedipalp. Anal operculum finely granular

Chelicerae (Fig. 3B-C). Basichelicerite finely and uniformly granular with some rounded protuberances in basal and ectal margins, two ectodistal small setiferous protuberances. Movable finger with row of eight teeth; fixed finger with five triangular teeth, decreasing in size from distal to basal part of finger.

Pedipalps (Fig. 3A). Trochanter with strong ventral apophysis. Femur dorsally convex without pronounced dorsal keel or tubercles, with ventral row of ten well-formed setiferous tubercles and a mesodistal process. Patella with mesal keel. Shallow slit along tibia mesal surface, separating dorsal and ventral sides.

Legs (Fig. 1B, E-F). Uniformly granular, femora III and IV slighted curved backwards. Coxae I-IV with prolateral conical apophyses, I and II larger than III and IV. Tarsal claws of legs III and IV smooth. Tarsal counts: 5(3)/6(3)/5/5.

Color (Fig. 1). Body and appendages background Strong Orange Yellow (68) mottled in Dark Yellowish Brown (78), ladder mask Pale Greenish Yellow (104). Pedipalpus as well as trochanters and tarsomeres of legs Light Greenish Yellow (101).

\section{Female}

Dorsal scutum and Fe IV shorter than males, with coda wider. Basitarsomeres I, III and IV not enlarged.

Variation (Fig. 2)

Pattern of yellow spots varying from an immaculate dorsal scutum to a well-filled ladder mask.

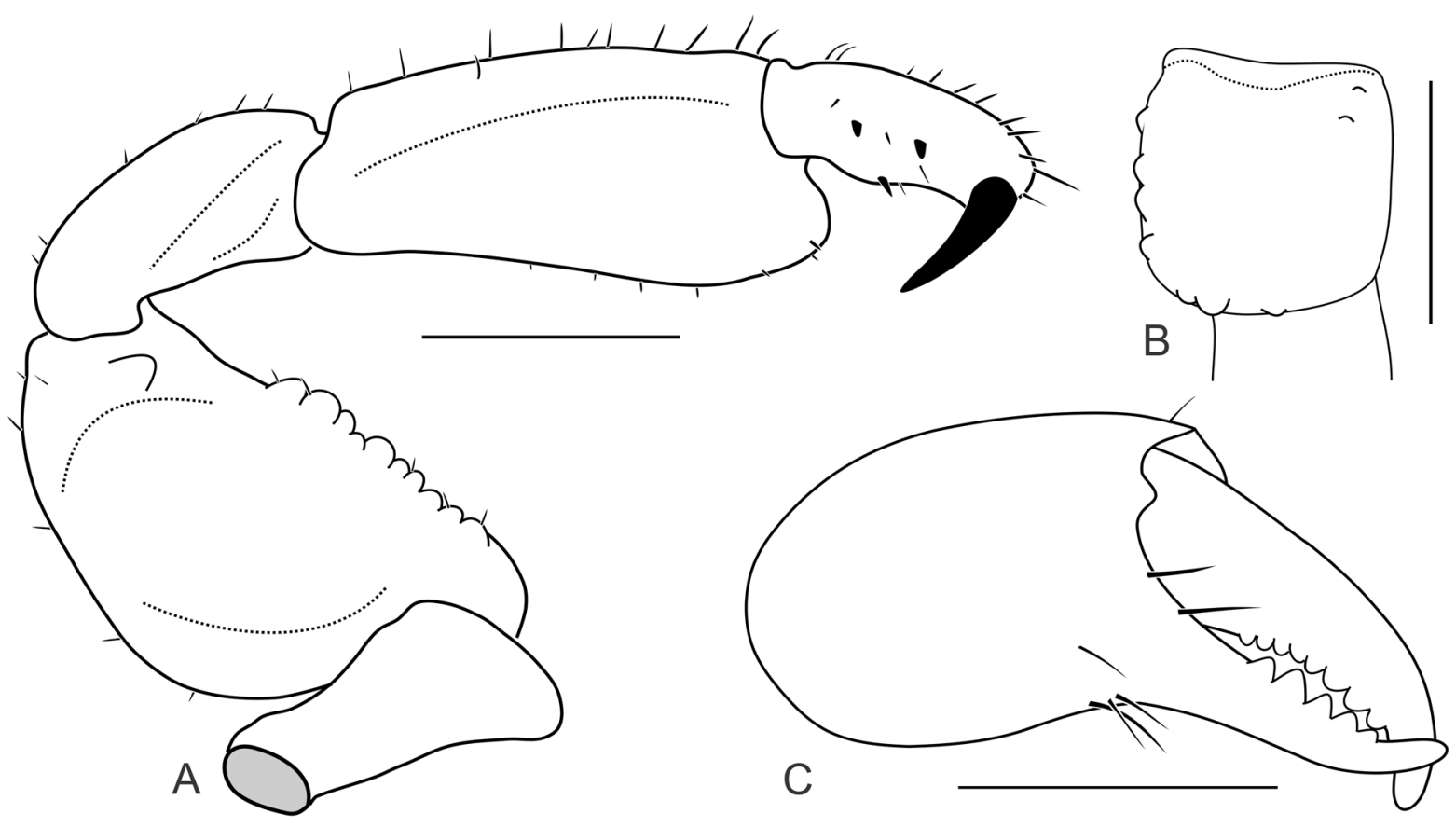

Fig. 3. Libitia bipunctata Sørensen, 1932, đ̊ (ICN-AO 470). A. Left pedipalp, ventral view. B. Left cheliceral hand, dorsal view. C. Left chelicera, dorsal view. Scale bars $=1 \mathrm{~mm}$. 


\section{Habitat}

Some specimens (material examined) were collected in leaf litter and under rocks from High-Andean forest to Paramo, between 2600-3660 m, using both manual collect and passive methods, as a pitfall or 'necrotrampa' used for animals with affinity for decomposed organic matter.
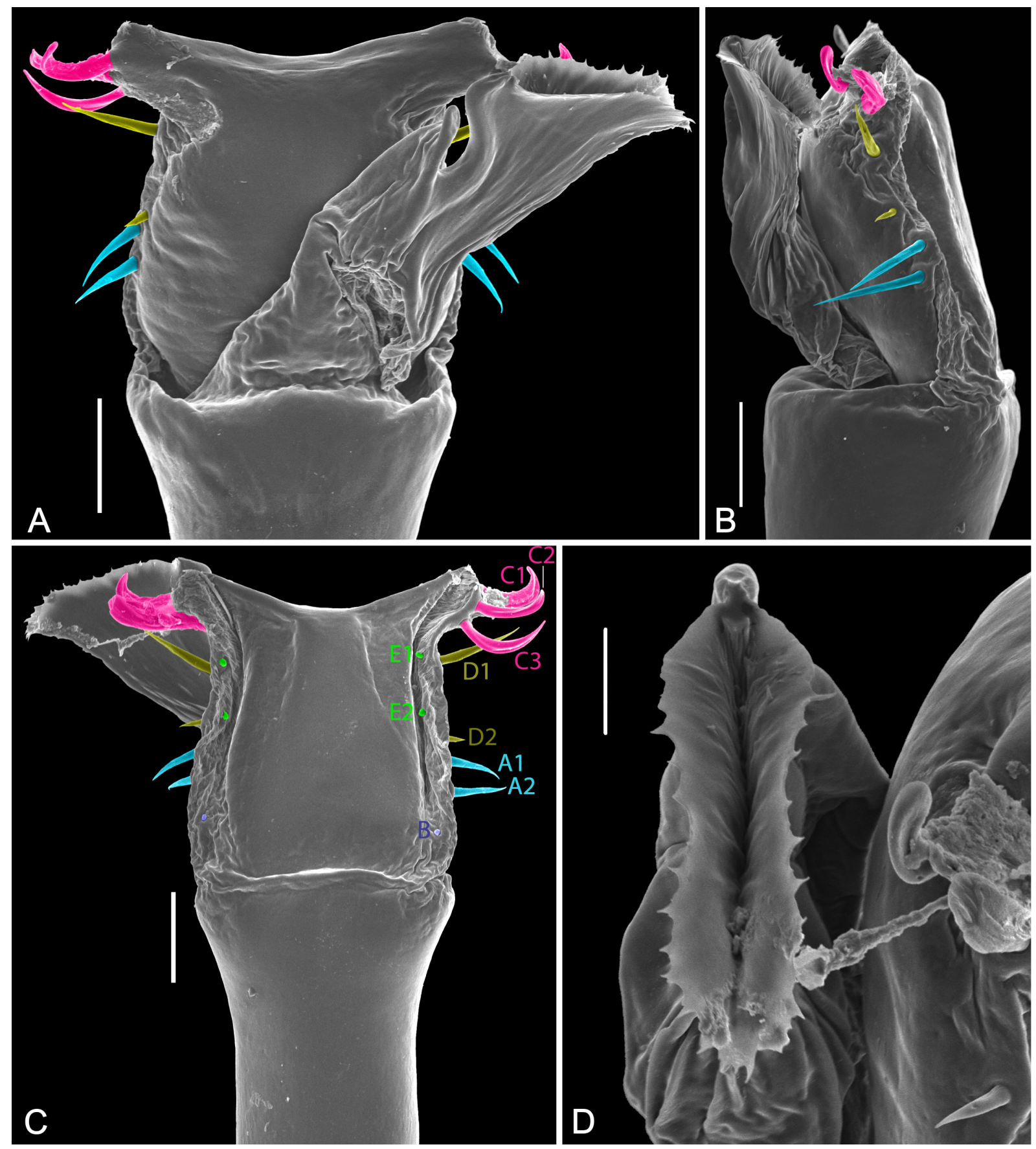

Fig. 4. Libitia bipunctata Sørensen, 1932, ठ̊ (ICN-AO 419), distal part of penis. A. Dorsal view B. Right lateral view. C. Ventral view, macrosetae colorised and numbered. D. Stylus, dorsal view. Scale bars: $\mathrm{A}-\mathrm{C}=50 \mu \mathrm{m} ; \mathrm{D}=20 \mu \mathrm{m}$. 


\section{Libitia cordata (Gervais, 1844)}

Figs 5-8, 14

Cosmetus cordatus Gervais, 1844: 117, pl. 46, fig. 9 [“Cosmète coeur”].

Libitia cordata - Butler 1873: 115. — Simon 1879: 216. - Roewer 1912: 12; 1923: 293. — MelloLeitão 1923: 108; 1932: 53; 1933: 109.

Libitia (Libitia) cordata - Sørensen in Henriksen 1932: 419.

non "Phalangium fusco-ferrugineum" - Olivier 1792: 125 [unavailable name].

\section{Diagnosis}

Can be separated from all the other species of the genus in having a heart-shape blot in areas I and II, without invading the carapace (Fig. 5A-B).

\section{Etymology}

The name is derived from the Latin adjective 'cordatus', meaning 'heart shaped'.

\section{Material examined}

\section{Holotype}

COLOMBIA $\bullet$ +; without further locality data; MNHN.

\section{Other material}

COLOMBIA - Cundinamarca Department • 3 $\widehat{\jmath}, 11$ 우; Bogotá, Usme, Parque Entrenubes, Cerro Juan Rey; $4.521586^{\circ}$ N, 74.097580 W; 2700 m a.s.1.; 23-25 May 2003; L. Benavides leg.; ICN-AO 421
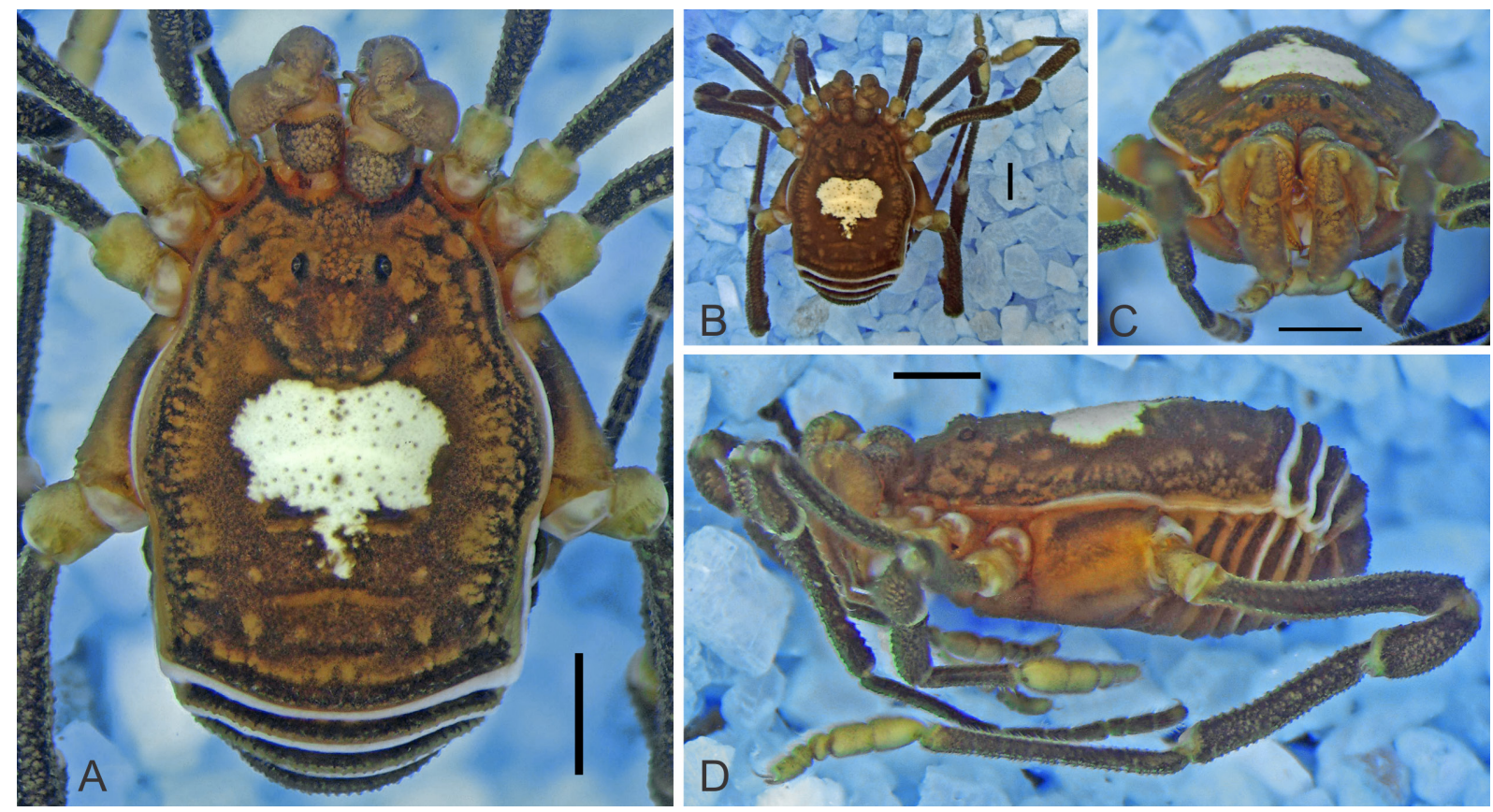

Fig. 5. Libitia cordata (Gervais, 1844), đ̊ (ICN-AO 1040), habitus. A. Dorsal view. B. Dorsal view, panoramic. C. Frontal view. D. Lateral right view. Scale bars $=1 \mathrm{~mm}$. 


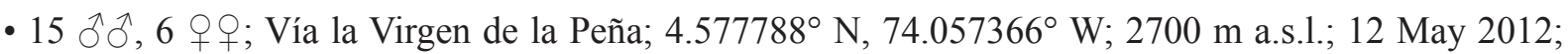
M. Medrano and A. García leg.; ICN-AO 1040.

\section{Doubtful/unconfirmed records}

"Venezuela", Páramo "Boydla", road to "Choact" [not located, probably Colombia, between Bogotá and Choachí] (Sørensen in Henriksen 1932). Guyana, Brazil (Simon 1879; Roewer 1912, 1923). Ecuador, Chimborazo, Simbabe (Roewer 1923)

\section{Remarks}

Olivier's species is not an available name according to ICZN because the paper it was described in is not consistent with binominal nomenclature.

\section{Redescription}

Male (ICN-AO 1040)

MeAsurements. $\mathrm{CL}=1.6, \mathrm{AL}=2.7, \mathrm{CW}=2.5, \mathrm{AW}=3.4, \mathrm{IOD}=0.6, \mathrm{Fe} \mathrm{I}=1.8, \mathrm{Ti} \mathrm{I}=1.3, \mathrm{Fe} \mathrm{II}=3$, $\mathrm{Ti} \mathrm{II}=2, \mathrm{Fe} \mathrm{III}=2.5$, Ti III $=1.6, \mathrm{Fe} \mathrm{IV}=2.8$, Ti IV $=2.1$.

Dorsum (Figs 5-6). Dorsal scutum alpha-type, areas I-III, anterior and posterior margin of scutum, and lateral margins with granules. Free tergites with rows of granules and anal operculum finely granular. Posterior margin of dorsal scutum convex. Large white-yellowish blot invading entirely areas I and II and invading medially area III.
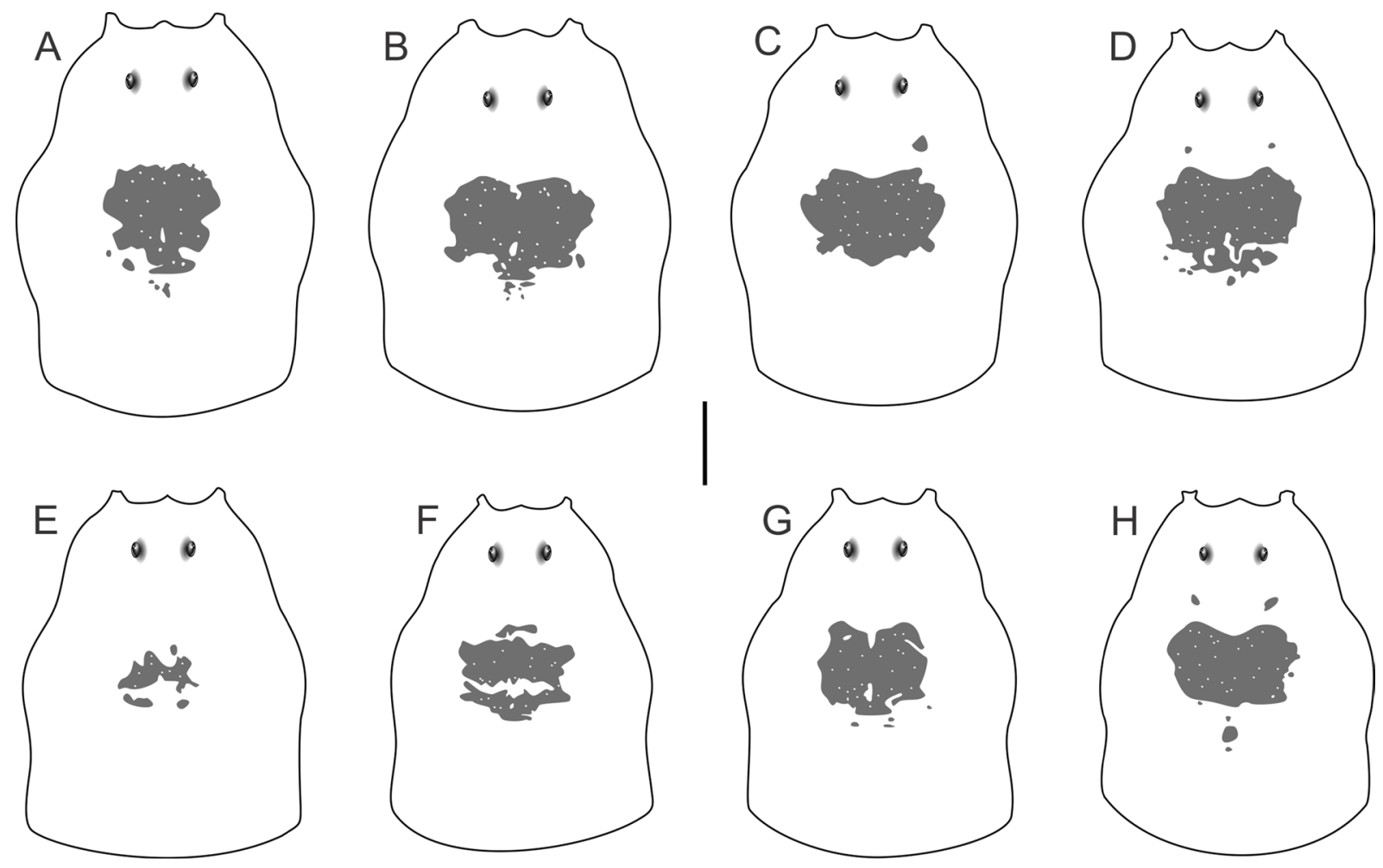

Fig. 6. Libitia cordata (Gervais, 1844), variation of spot pattern on dorsal scutum. A-D. $\widehat{\jmath}$. A. ICN-AO 1040. B. ICN-AO 421. C. ICN-AO 1040. D. ICN-AO 1040. E-H. 우․ E-F. ICN-AO 421. G-H. ICN-AO 1040. Scale bar $=1 \mathrm{~mm}$. 
VENTER. Free sternites finely granular; coxae II-IV finely and uniformly granular; coxa I with longitudinal row of tubercles and smooth area corresponding to lace area of pedipalp. Anal operculum finely granular.

Chelicerae (Fig. 7F-G). Basichelicerite finely and uniformly granular without notable tubercles, ectodistal small setiferous protuberance; movable finger with row of nine sharp teeth; fixed finger with six triangular teeth, decreasing in size from distal to basal part of finger.

Pedipalps (Fig. 7D-E). Trochanter with strong ventral apophysis. Femur dorsally convex without pronounced dorsal keel or tubercles, with ventral row of three well-formed setiferous tubercles and a mesodistal process. Patella with mesal keel. Shallow slit along tibia mesal surface, separating dorsal and ventral sides.

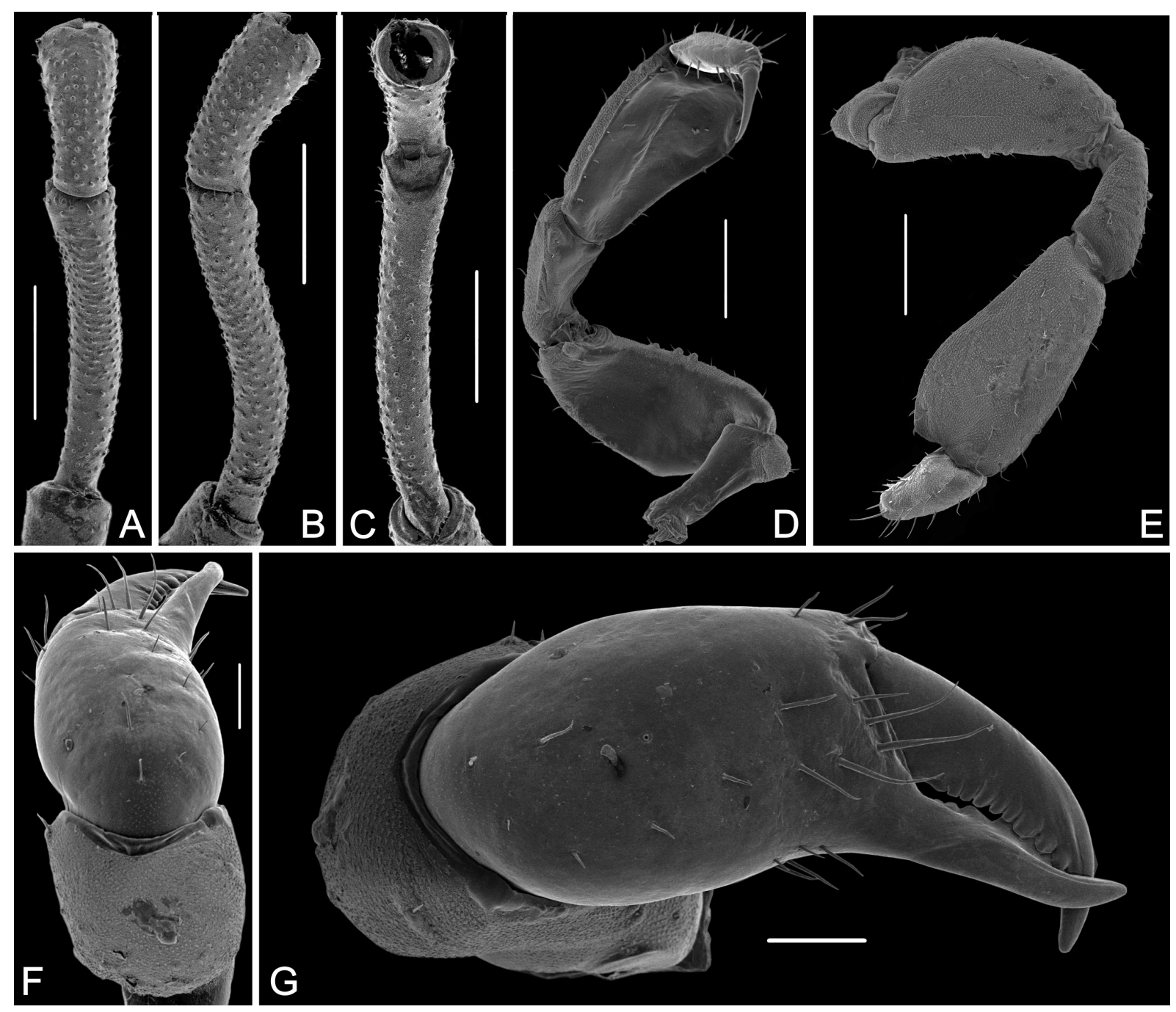

Fig. 7. Libitia cordata (Gervais, 1844), $\widehat{\partial}$ (ICN-AO 1040). A-C. Left femur IV, dorsal, prolateral and ventral view, respectively. D-E. Right pedipalp, ventral and dorsal view, respectively. F-G. Left chelicera, dorsal and frontal view, respectivelly. Scale bars: A-C $=1 \mathrm{~mm}, \mathrm{D}-\mathrm{E}=500 \mu \mathrm{m} ; \mathrm{F}-\mathrm{G}=200 \mu \mathrm{m}$. 
Legs (Figs 5, 7A-C). Coxa IV granulated with distal prodorsal small apophysis. Coxa IV granulated. Femur IV substraight, with two longitudinal ventral rows of small tubercles along entire length. Tarsal counts: $5(3) / 6(3) / 5 / 5$.

Color (Fig. 5). Body background Brilliant Orange Yellow (67) mottled in Dark Yellowish Brown (78) and Brownish Black (65) for margins of dorsal scutum and appendages, ladder mask Pale Greenish Yellow (104). Pedipalpus as well as trochanters and tarsomeres of legs Light Greenish Yellow (101).

Female (ICN-AO 1040)

Measurements. $\mathrm{CL}=1.7, \mathrm{AL}=3.1, \mathrm{CW}=2.6, \mathrm{AW}=3.4, \mathrm{IOD}=0.6, \mathrm{Fe} \mathrm{I}=1.6, \mathrm{Ti} \mathrm{I}=1.3, \mathrm{Fe} \mathrm{II}=2.6$, $\mathrm{Ti} \mathrm{II}=1.9$, Fe III $=2.6$, Ti III $=1.5, \mathrm{Fe}$ IV $=2.9$, Ti IV $=2.4$. Dorsal scutum longer than in males, with coda wider. Basitarsomeres I, III and IV not enlarged. Tarsal counts: 5(3)/6(3)/5/5.

\section{Variation (Fig. 6)}

Pattern of yellow spots varying from a complete spot in form of a heart, to a dissociated version of the spot in the middle of areas I and II. In some cases, small spots are present in posterior margin of cephalothorax.
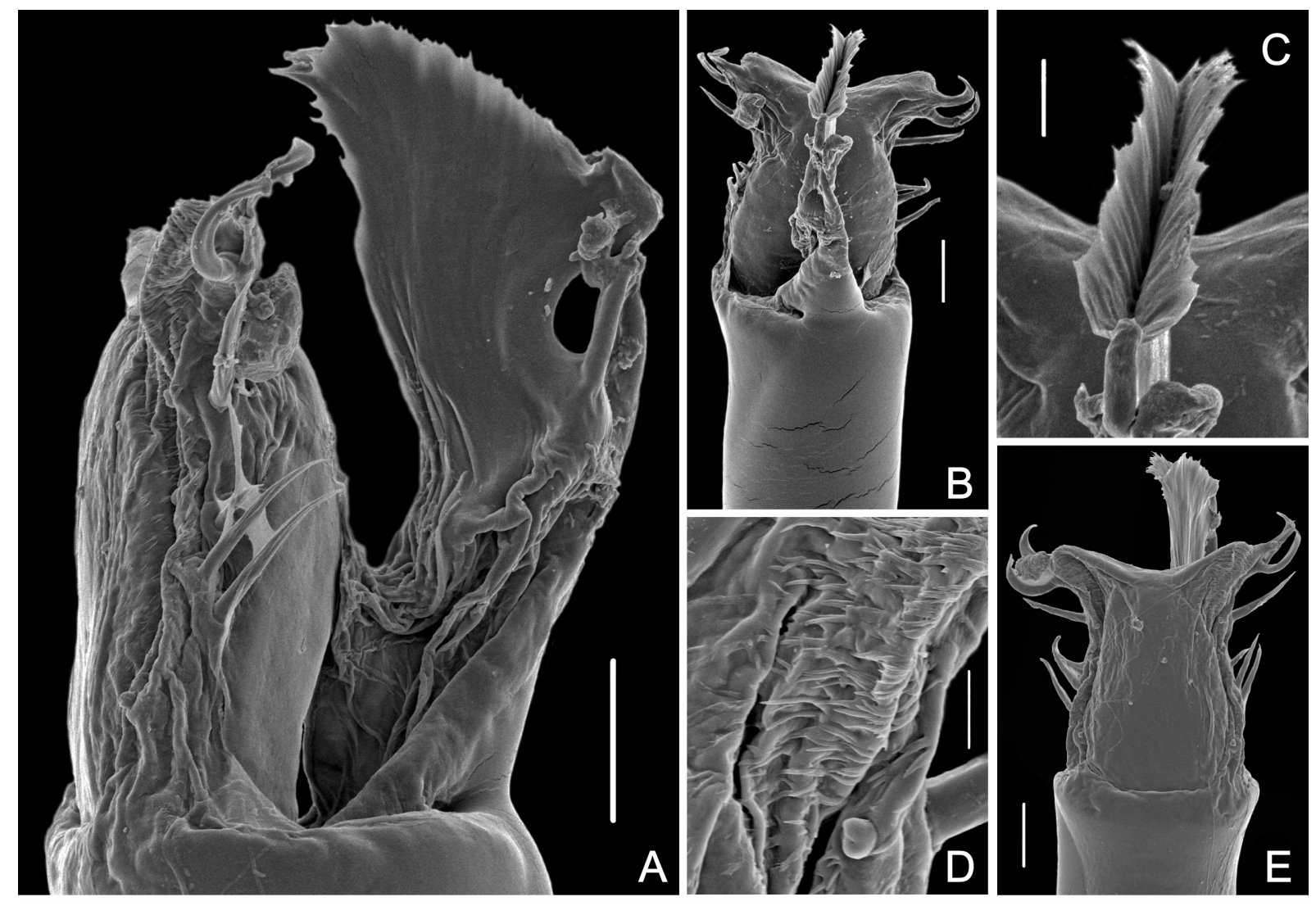

Fig. 8. Libitia cordata (Gervais, 1844), ô (ICN-AO 1040), distal part of penis. A. Left lateral view. B. Dorsal view. C. Stylus. D. Lateral portion of ventral plate, microsetae. E. Ventral view. Scale bars: A, $\mathrm{E}=50 \mu \mathrm{m} ; \mathrm{B}=100 \mu \mathrm{m} ; \mathrm{C}=20 \mu \mathrm{m} ; \mathrm{D}=10 \mu \mathrm{m}$. 
Libitia gandalf sp. nov. urn:lsid:zoobank.org:act:FBDC8502-2FE9-4413-B4C5-CD74D8D68EA1

Figs 9-10, 14

\section{Diagnosis}

Can be separated from all the other species of the genus in having the blots pattern invading carapace and occupying entirely area I of mesotergum. Scutal groove between carapace and area I without white marks forming a smile-like pattern immersed in a white 'beard' and one spot without filling at each side of that 'smile'.

\section{Etymology}

Noun in apposition from the fictional character Gandalf the White, one of the protagonists in J.R.R. Tolkien's novels The Hobbit and The Lord of the Rings. Blot pattern of dorsal scutum resembles the white beard of the character while smiling.

\section{Material examined}

\section{Holotype}

COLOMBIA - đ̄; Meta Department, San Juanito, Parque Nacional Natural Chingaza; $4.471391^{\circ}$ N, $73.675435^{\circ} \mathrm{W} ; 2990 \mathrm{~m}$ a.s.l.; IAvH-I-69.
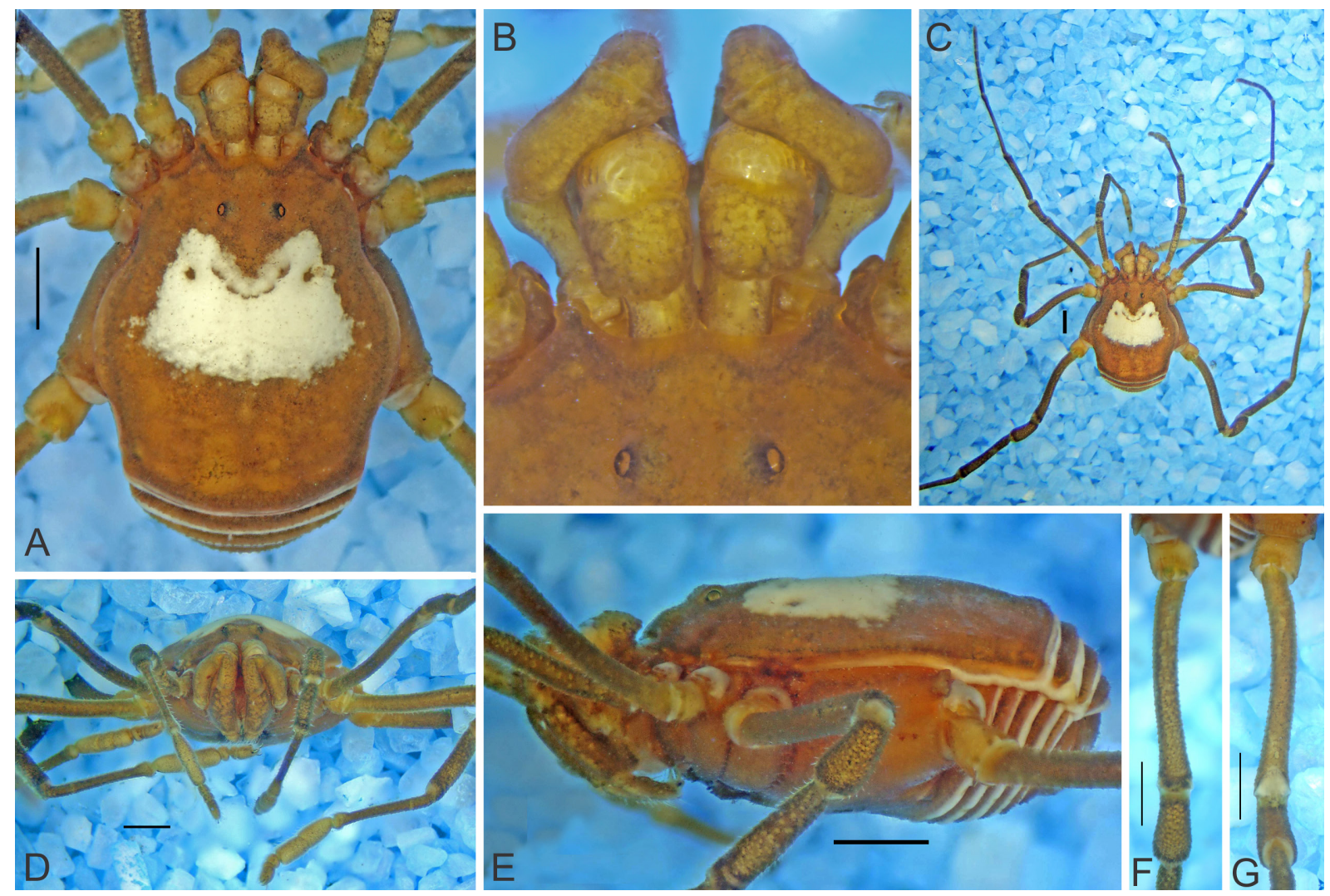

Fig. 9. Libitia gandalf sp. nov., holotype, ồ (IAvH-I-69), habitus. A. Dorsal view. B. Dorsal view, anterior margin of carapace. C. Dorsal view, panoramic. D. Frontal view. E. Right lateral view. F-G. Right femur IV, dorsal and ventral view, respectively. Scale bars $=1 \mathrm{~mm}$. 


\section{Paratype}

COLOMBIA $・ 1$; ; same collection data as for holotype; IAvH-I-86.

\section{Description}

Male holotype (IAvH-I-69)

Measurements. $\mathrm{CL}=1.7, \mathrm{AL}=2.6, \mathrm{CW}=2.6, \mathrm{AW}=3.7, \mathrm{IOD}=0.6, \mathrm{Fe} \mathrm{I}=2$, $\mathrm{Ti} \mathrm{I}=1.4, \mathrm{Fe} \mathrm{II}=3.4$, $\mathrm{Ti} \mathrm{II}=2.3$, Fe III $=2.9$, Ti III $=1.7$, Fe IV $=3.3$, Ti IV $=2.7$.

Dorsum (Fig. 9A-E). Dorsal scutum alpha-type, areas I-III, anterior and posterior margin of scutum, and lateral margins with granules. Free tergites with rows of granules and anal operculum finely granular. Posterior margin of dorsal scutum convex. Area I and posterior part of carapace with yellow solid blot, except for a fragmented area in scutal groove and one unfilled spot at each side.

VENTER. Free sternites finely granular; coxae II-IV finely and uniformly granular; coxa I with longitudinal row of tubercles and smooth area corresponding to lace area of pedipalp. Anal operculum finely granular.

LEGS (Fig. 9F-G). Coxa IV granulated with distal prodorsal small apophysis. Coxa IV granulated. Femur IV substraight, with two longitudinal ventral rows of small tubercles along entire length. Tarsal counts: $5(3) / 7(3) / 5 / 5-6$.

Color (Fig. 9). Body background and appendages Moderate Orange Yellow (71) mottled in Deep Yellowish Brown (75), ladder mask Pale Greenish Yellow (104). Trochanters and tarsomeres of legs Light Greenish Yellow (101).

\section{Female}

Similar to males, with coda longer. Basitarsomeres I, III and IV not enlarged. Tarsal counts: 5(3)/6$7(3) / 6 / 6$.

\section{Variation}

No remarkable variation encountered in spots of DS in the examined specimens.
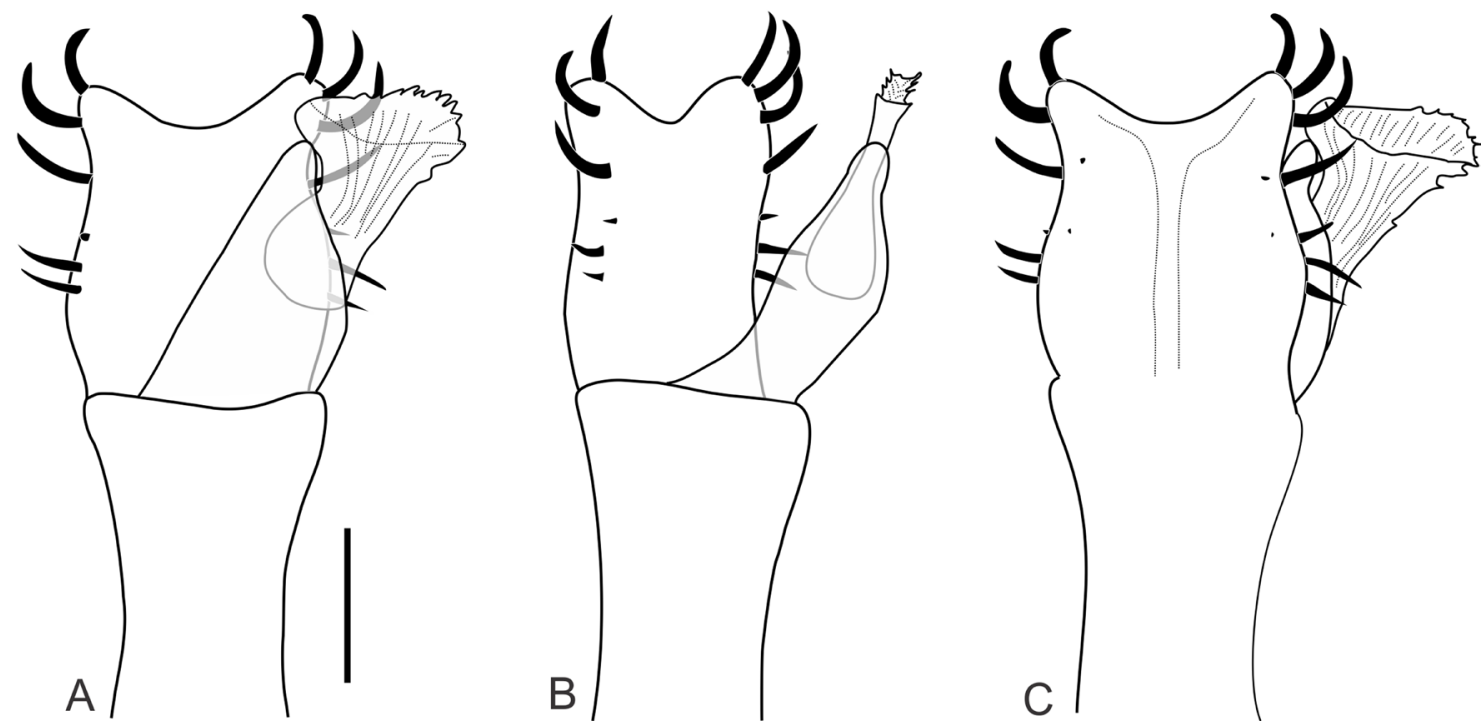

Fig. 10. Libitia gandalf sp. nov., holotype (IAvH-I-69), distal part of penis. A. Dorsal view. B. Laterodorsal view. C. ventral view. Scale bar $=50 \mu \mathrm{m}$. 


\section{Libitia iguaque sp. nov. \\ urn:1sid:zoobank.org:act:E1CD5C3A-5C52-461C-A2D5-F0785E40A931}

Figs $11-12,14$

\section{Diagnosis}

Can be separated from all the other species of the genus in having the coda shorter than mid-bulge, maximum width of dorsal scutum equal to maximum length (Fig. 11A). Three basitarsomeres in legs I and III (Fig. 11B-C). VP of the penis with MS D1 equally distanced from MS D2 and MS C2 (Fig. 12A-D).

\section{Etymology}

Noun in apposition from Iguaque, which in the Chibcha language means 'vigorous mountain' and was the cultural epicenter in the Amerindian period; as sacred territory it represented, for the Muiscas, the universe in continuous regeneration: birth, fecundity, fertility and initiation, symbol of ascent and interior knowledge. Also, it is the name of the Sanctuary that is the type locality of the species.

\section{Material examined}

\section{Holotype}

COLOMBIA • ${ }^{\wedge}$; Boyacá Department, Santuario de Fauna y Flora Iguaque; $5.70175^{\circ} \mathrm{N}, 73.456222^{\circ} \mathrm{W}$; 2941 m a.s.1.; 26-27 Nov. 2011; A. García and A.B. Kury leg.; MNRJ 19765.

\section{Paratypes}

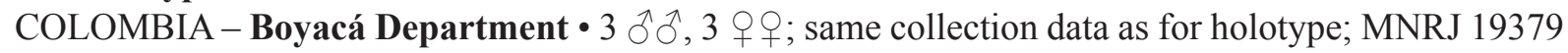

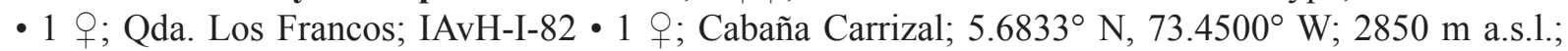
IAvH-I-91 • 1 \%; same collection data as for preceding; IAvH-I-92 • 1 क ; Villa de Leyva; $5.720016^{\circ} \mathrm{N}$, 73.457901 ${ }^{\circ} \mathrm{W} ; 2900$ m a.s.1.; 20 Aug. 1998; IAvH-I-17• 1 क; Villa de Leyva, S.F.F Iguaque; $5.697856^{\circ} \mathrm{N}$, $73.453133^{\circ} \mathrm{W} ; 10 \mathrm{Apr} .2001$; coprotrampa; ICN-AO 771.
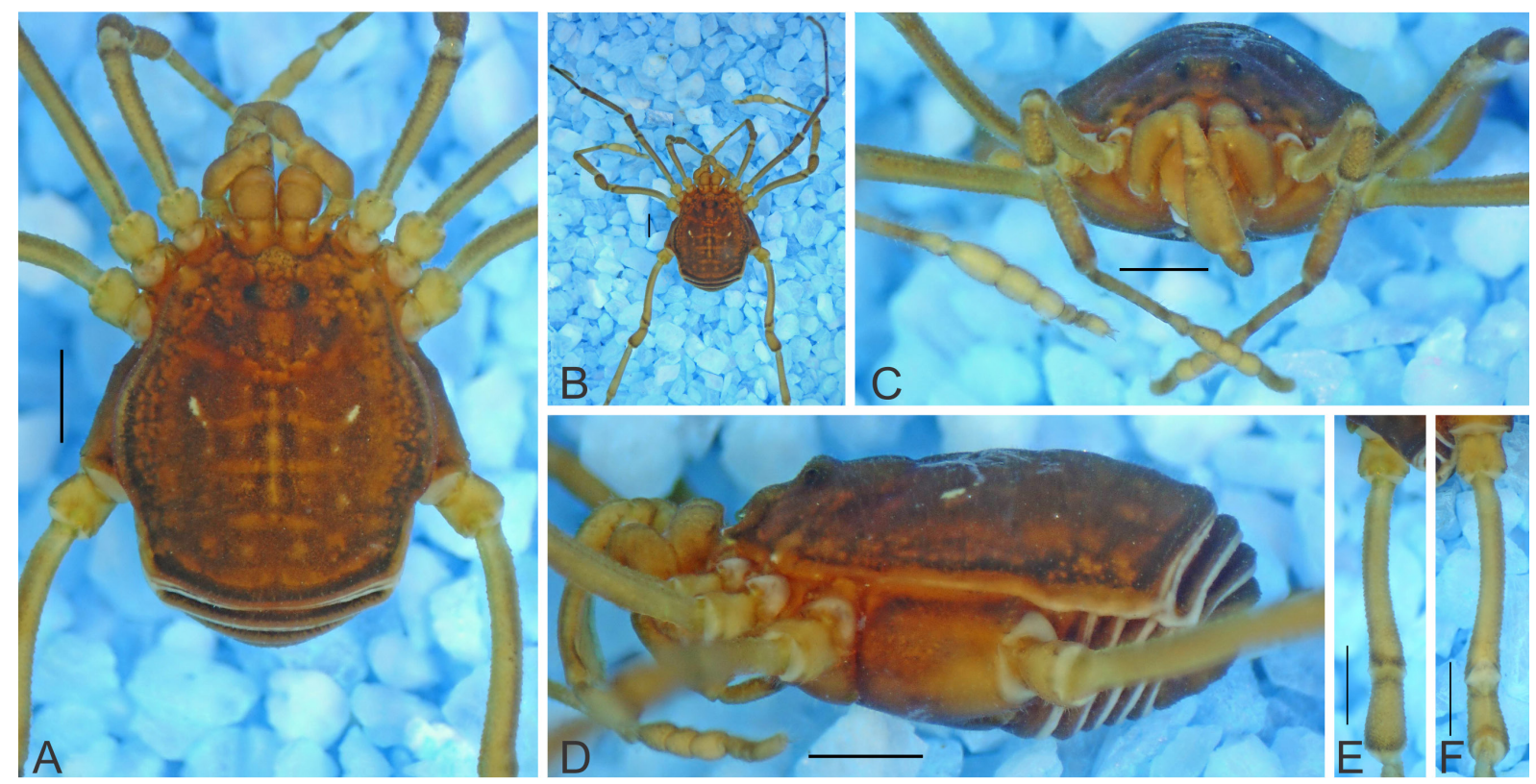

Fig. 11. Libitia iguaque sp. nov., $\widehat{\partial}$ (MNRJ 19765), habitus. A. Dorsal view. B. Dorsal view, panoramic. C. Frontal view. D. Lateral right view. E-F. Right femur IV, dorsal and ventral view, respectively. Scale bars $=1 \mathrm{~mm}$. 

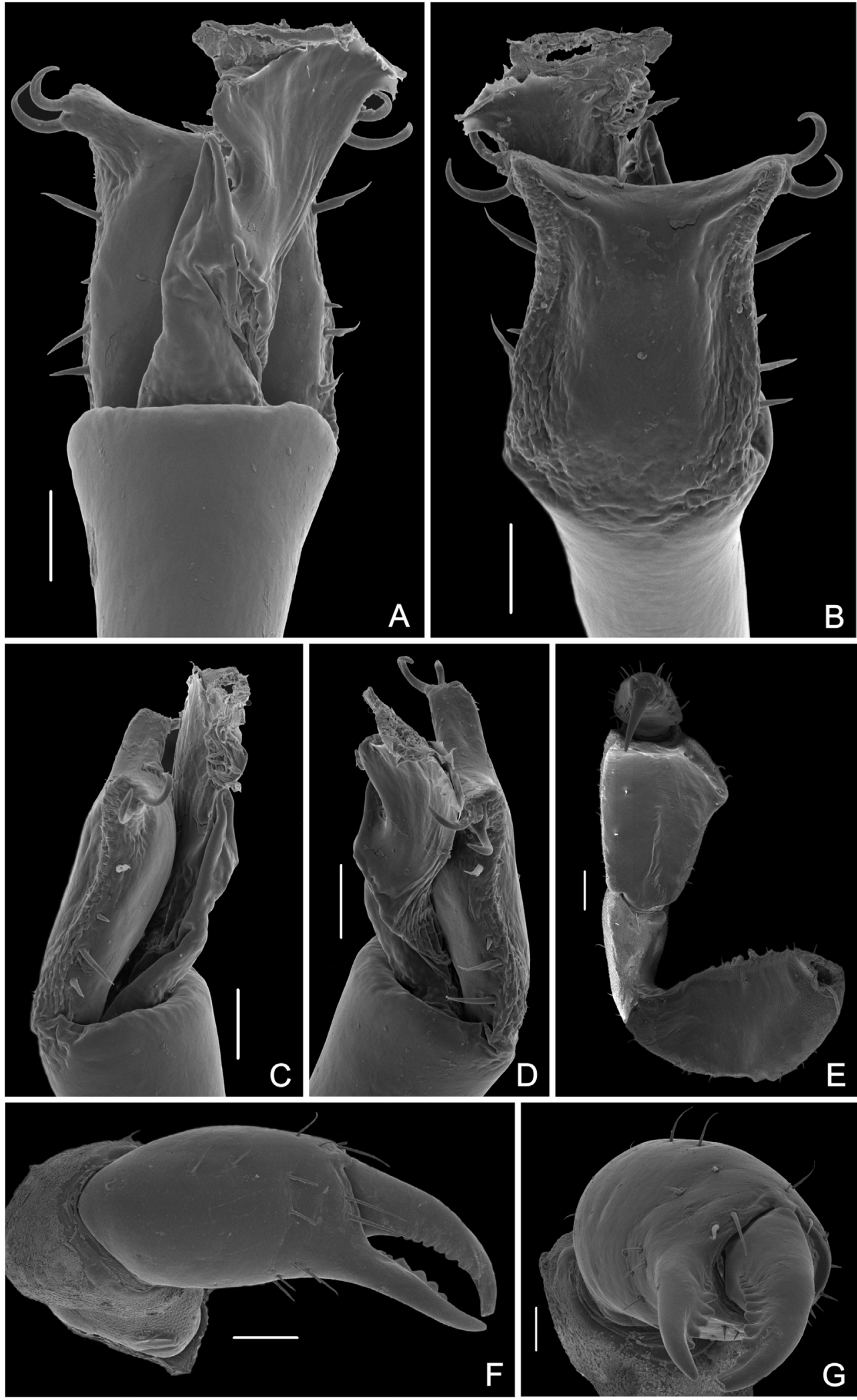

Fig. 12. Libitia iguaque sp. nov., $\widehat{\partial}$ (MNRJ 17379). A-D. Distal part of penis. A. Dorsal view. B. Ventral view. C. Left lateral view. D. Right lateral view. E. Right pedipalp, ventral view. F-G. Left chelicera, dorsal and frontal view, respectively. Scale bars: $A-D=50 \mu \mathrm{m} ; \mathrm{E}-\mathrm{F}=200 \mu \mathrm{m} ; \mathrm{G}=100 \mu \mathrm{m}$. 


\section{Description}

Male holotype (MNRJ 19765)

Measurements. $\mathrm{CL}=1.5, \mathrm{AL}=2.6, \mathrm{CW}=2.7, \mathrm{AW}=3.6, \mathrm{IOD}=0.6$, $\mathrm{Fe} \mathrm{I}=2$, $\mathrm{Ti} \mathrm{I}=1.3, \mathrm{Fe} \mathrm{II}=3$, $\mathrm{Ti} \mathrm{I}=$ $2.1, \mathrm{Fe}$ III $=2.8$, Ti III $=1.6$, Fe IV $=2.9$, Ti IV $=2.5$.

Dorsum (Fig. 11A-D). Dorsal scutum alpha-type, areas I-III, anterior and posterior margin of scutum, and lateral margins with granules. Free tergites with rows of granules and anal operculum finely granular. Posterior margin of dorsal scutum convex. Marginal lateral grooves of areas I and II with fragmented yellow rails.

VENTER. Free sternites finely granular; coxae II-IV finely and uniformly granular; coxa I with longitudinal row of tubercles and smooth area corresponding to lace area of pedipalp. Anal operculum finely granular.

Chelicerae (Fig. 12F-G). Basichelicerite finely and uniformly granular covered without notable tubercles, ectodistal small setiferous protuberance; movable finger with row of eight sharp teeth; fixed finger with seven triangular teeth (the middle teeth are larger).

Pedipalps (Fig. 12E). Trochanter with strong ventral apophysis. Femur dorsally convex without pronounced dorsal keel or tubercles, with ventral row of three well-formed setiferous tubercles and a mesodistal process. Patella with mesal keel. Shallow slit along tibia mesal surface, separating dorsal and ventral sides.

Legs (Fig. 11E-F). Coxa IV granulated with distal prodorsal small apophysis. Femur IV substraight, with two longitudinal ventral rows of small tubercles along entire length. Tarsal counts: $6(3) / 8-7(3) / 6 / 6$.

Color (Fig. 11). Body background Strong Yellowish Brown (74) mottled in Deep Yellowish Brown (75), ladder mask Pale Greenish Yellow (104). Appendages (except coxae) Brilliant Yellow (83).

\section{Female}

Similar to males, with coda longer. Basitarsomeres I, III and IV not enlarged. Tarsal counts (MNRJ 19379): 6(3)/7-6(3)/6/6.

\section{Variation}

No remarkable variation was encountered in spots of DS in the specimens examined.

Genus Metalibitia Roewer, 1912

Metalibitia fusca (Simon, 1879) comb. nov.

Libitia fusca Simon, 1879: 217.

Libitia fusca - Roewer 1912: 12; 1923: 294; 1928: 552. — Mello-Leitão 1932: 53. — Kury 2003: 65.

\section{Material examined}

Type

"SOUTH AMERICA" • ; without further locality data; MNHN (Coll Simon No 2795) (one unsexed specimen examined by photograph).

\section{Records}

"Paraguay", without further locality data (Roewer 1928). Brazil, "Pará", without further locality data (Mello-Leitão 1932). 


\section{Remarks}

We tentatively propose the new combination based on the external morphology (although examination of penis morphology is imperative to be certain) of the male type (MNHN) by the following features: (1) outline of dorsal scutum gamma-type; (2) eyes poorly spaced and ocularium without depression ("Mamelon oculaire assez grand, ovale transverse, bas, légèrement granuleux." Simon 1879); (3) areas IIII with paramedian tubercles and (4) dorsal scutum and coxa IV without yellow spots. The impossibility to examine the holotype thoroughly and the "doubtful origin" of the specimen described by Simon does not allow us to verify whether this species corresponds to another already described species. It is very difficult to conclude whether the records provided by Roewer (1928) and Mello-Leitão (1932) are correct because both localities match with those of various species of Metalibitia (Coronato \& Pintoda-Rocha 2017).

\section{Genus Paecilaemella Roewer 1925}

Paecilaemella multimaculata (Wood, 1869) revalidated, comb. nov. Fig. 13

Gonyleptes multimaculatus Wood, 1869: 438, pl. 24, fig. 10 [junior subjective synonym of Cosmetus cordatus Gervais, 1844 by Butler (1873); synonymy disclaimed here].

Cynorta itacoaiensis H. Soares, 1970: 324. syn. nov.

Gonyleptes multimaculatus - Cokendolpher \& Peek 1991: 95.

Cranaus multimaculatus - Simon 1879: 241.

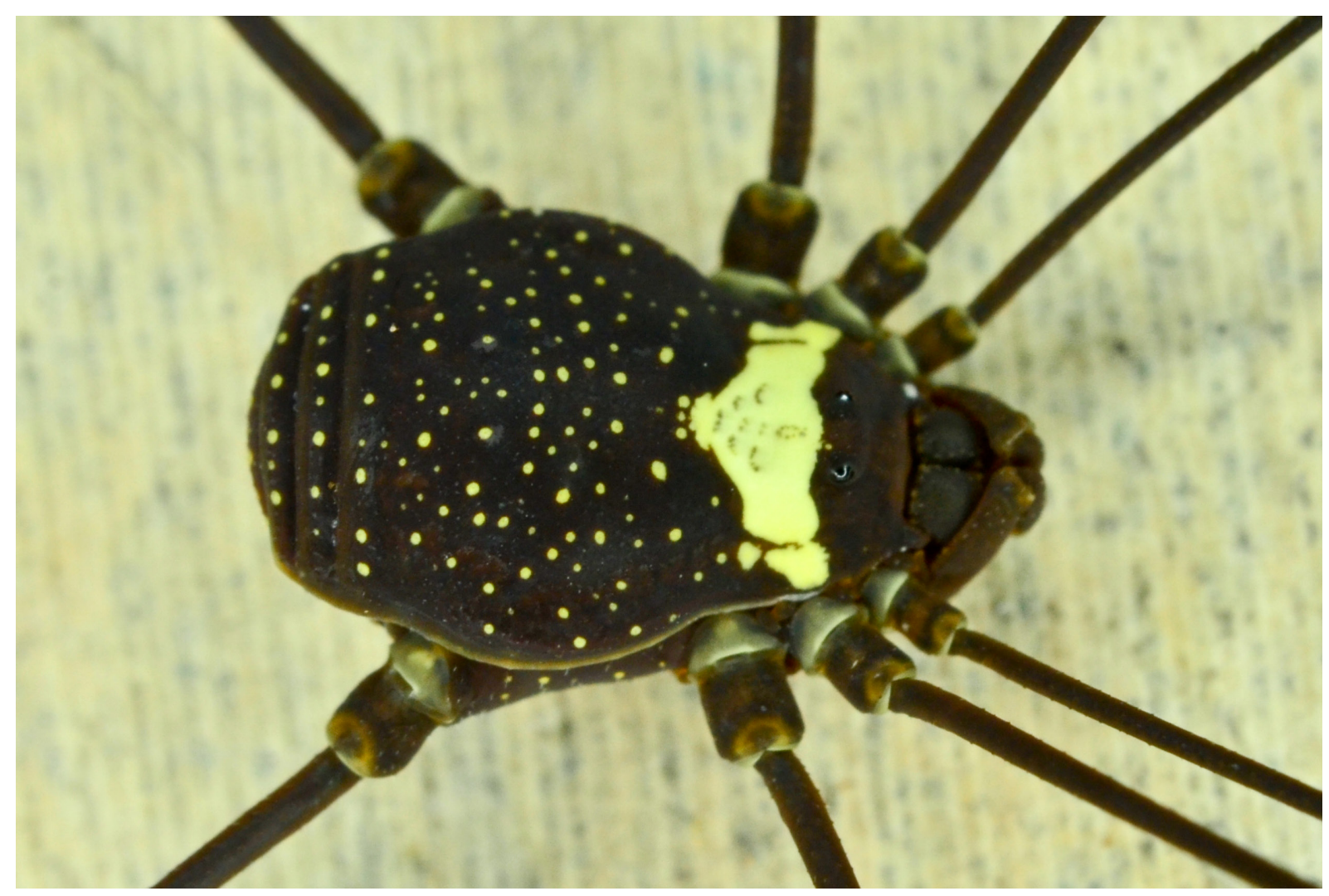

Fig. 13. Living specimen of Paecilaemella multimaculata (Wood, 1869) (CHNUFP) from Cruzeiro do Sul, Acre (photo courtesy of Leonardo Carvalho). 


\section{Type data}

Gonyleptes multimaculatus: Type(s), whereabouts unknown, from "Napo and Maravon" [Napo and Marañon rivers] [possibly the confluence of both rivers, near Iquitos, Loreto, Peru].

Cynorta itacoaiensis: $\widehat{\jmath}$, holotype (MNRJ 5059, examined), from Brazil, Amazonas, Upper Itaquaí River.

\section{Material examined}

BRAZIL • 1 क; Acre, Cruzeiro do Sul, proximidades do Aeroporto Internacional de Cruzeiro do Sul, rodovia AC-405; 7.595972 ${ }^{\circ}$ S, $72.766528^{\circ}$ W; 190 m a.s.l.; 30 Oct. 2016; L.S. Carvalho leg.; CHNUFPI 2317.

\section{Remarks}

The synonymy of Gonyleptes multimaculatus with Cosmetus cordatus, established by Butler (1873), is not supported here because the former possess the following features (Fig. 13): (1) large body (>6 mm); (2) main solid white spot mostly occupying the cephalothorax; (3) scattered white dots on abdomen, free tergites and coxa IV; (4) long and smooth legs (femur IV longer than the total length of the dorsal scutum); (5) dorsal scutum beta-type and (6) tarsal counts more numerous (6/14/8/9). All those features also show that Gonyleptes multimaculatus does not belong to the genus Libitia, better fitting the diagnosis of the recently revalidated genus Paecilaemella (see Kury \& Medrano 2018). The specimens of Gonyleptes multimaculatus examined by Wood (1869) were damaged and did not allow an unambiguous diagnosis as a cosmetid, since the pedipalps are missing. Butler (1873), besides his precipitated specific synonymy, already showed the relation of the species with cosmetids. After a century, H. Soares (1970) described Cynorta itacoaensis from the Itacoaí River in upper Amazonas with a description and an illustration that entirely match those of Wood's species. Therefore, we propose that Cynorta itacoaiensis H. Soares, 1970 is a junior synonym of Paecilaemella multimaculata (Wood, 1869) comb. nov.

\section{Discussion}

Although cosmetids are conspicuous and showy animals with a remarkable diversity (second largest family in Neotropics), its taxonomy is in very bad shape. Little has changed in the conformation of the family as a whole (except for the recent transfer from Gonyleptidae of the genus Platygyndes Roewer, 1943 by Pinto-da-Rocha \& Hara 2011) and the subfamilies remain characterized by a single and variable feature since early $20^{\text {th }}$ century. Nonetheless, the internal conformation is under constant and fundamental changes as re-diagnoses of diverse genera, generic synonyms or new combinations (Kury \& Barros 2014; García \& Kury 2017; Kury \& Medrano 2018).

Here, we recognize and diagnose the genus Libitia, providing important morphological information such as the size and details of the wattle in the penial stylus, that in cosmetids goes from an extremely reduced membrane with just a few "stylar barbs" (defined in Medrano \& Kury 2018) as in Sibambea Roewer, 1917 to the extremely incrassated one without stylar barbs in species of Libitia. Other cosmetids with a similar external appearance to species of Libitia and inhabiting high landscapes in the Andes of Ecuador and Colombia (Fig. 14), such as Ambatoiella, Eulibitia and Rhaucus, may be differentiated from Libitia by their penial morphology which possesses a small wattle with stylar barbs.

Besides the relationship of this genus with Eulibitia and Ambatoiella (Medrano \& Kury 2018), Libitia also shows a remarkable resemblance with the genus Oligovonones Caporiacco, 1951, sharing characteristics such as: (1) dorsal scutum alpha-type with slight constrictions, (2) spots in marginal part of the grooves (3) mesotergum unarmed and flat and (4) legs short and uniformly tuberculated, without spines. 
The morphology of tarsomeres was shown in Medrano \& Kury (2017) for different Andean cosmetids and seems to be very useful to diagnose some genera. Tarsomeres (counts) were widely used in opilionological taxonomy almost as an exclusive character to define if one species belonged to one genus or another, reaching its extreme with Goodnight \& Goodnight (1953). Although an exaggerated splitting vision may carry unjustifiable synonyms and taxonomical chaos (as already happened), the careful use of tarsal counts and other morphological traits may have a phylogenetic signal in suprageneric groups. Here we recognize a reduction in the number of basitarsomeres in legs I, III and IV in most species of Libitia. On the other hand, leg II by having a sensory function and being subject to environmental pressures is different from ambulatory legs (Martens 1978) and shows a remarkable intra- and interspecific variation in the number of basitarsomeres, so we recommend mainly the use of legs I, III and IV for taxonomic purposes.

The eastern cordillera in Colombia possesses great abundance of Páramos. Nonetheless, most of material present in biological collections is from areas near Bogotá. The complexity of the territory,

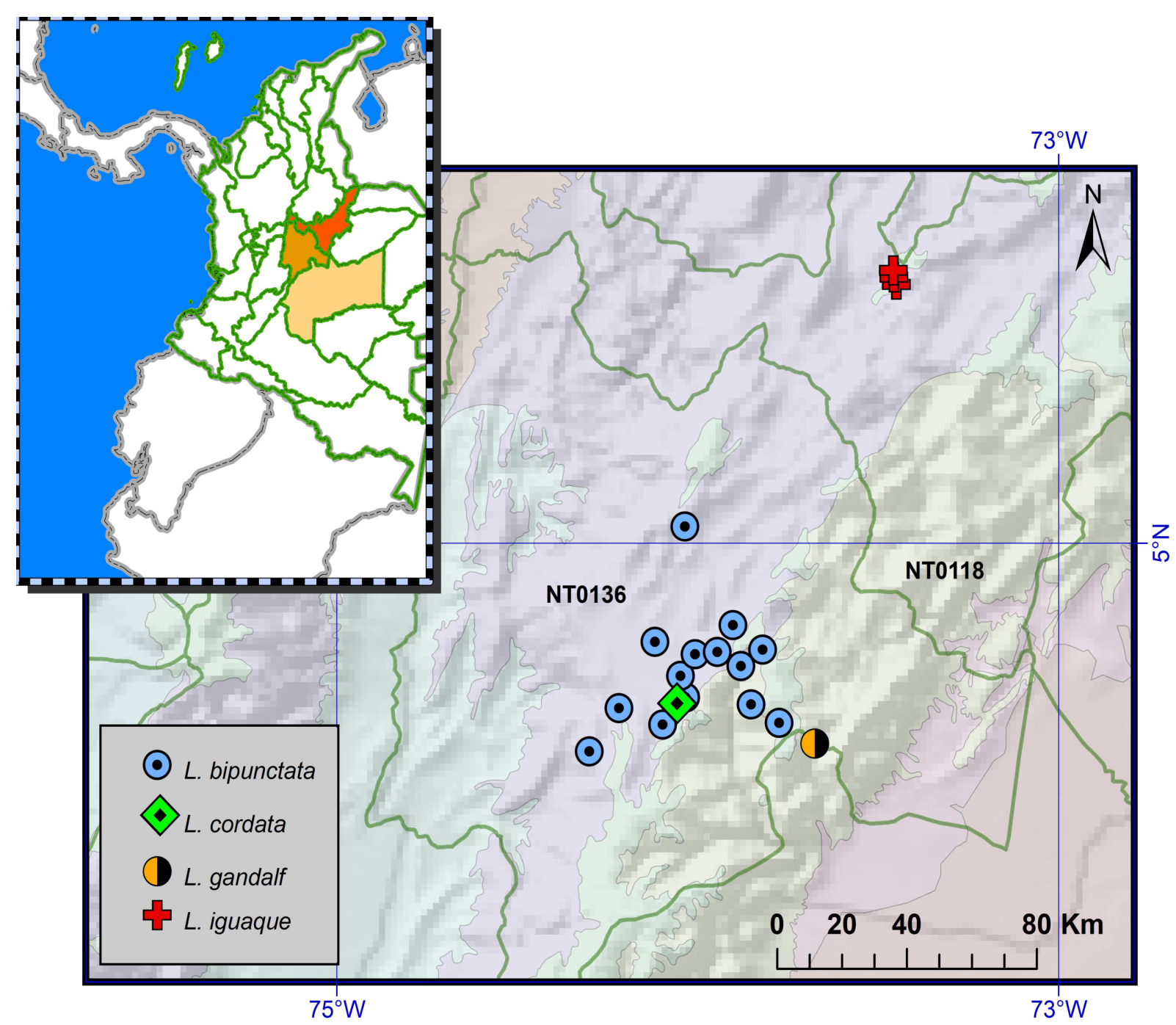

Fig. 14. Central Colombia, showing the distribution of species of Libitia Simon, 1879 (inset: NW SouthAmerica, for context). Highlighted Colombian departments are from north to south: Boyacá (red), Cundinamarca (orange) and Meta (yellow). 
low connectivity (roads) and security complexity, make these zones almost inaccessible and it is expected that new species of Libitia or even not yet discovered genera will be encountered in future investigations.

\section{Acknowledgements}

We thank the curators Dimitri Forero (MPUJ), Claudia Medina (IAvH) and Eduardo Florez (ICN) who loaned material. Elise-Anne Leguin and Ricardo Pinto-da-Rocha provided photographs of types in MNHN; Janet Beccaloni kindly assisted ABK during visits to BMNH in 2011 and 2013. Andrés García (MNRJ) participated in a short expedition with ABK, which led to the discovery of L. iguaque sp. nov. Leonardo Carvalho (UFPI) photographed and collected specimens of P. multimaculata and also carefully attended to the first author in a visit to UFMG. Brittany Damron kindly checked the accession number of the specimen in CHNUFPI. This study has been supported by grants \#306411/2015-6 from the Conselho Nacional de Desenvolvimento Científico e Tecnológico (CNPq, Produtividade em Pesquisa), \#200.085/2019 from Fundação de Amparo à Pesquisa do Estado do Rio de Janeiro (FAPERJ, Apoio Emergencial ao Museu Nacional) to ABK, scholarship from FAPERJ (\#E-26/200.605/2018) to LNA and scholarship from CAPES to MM.

\section{References}

Butler A.G. 1873. A monographic list of the species of the genus Gonyleptes, with descriptions of three remarkable new species. Annals and Magazine of Natural History 11 (62): 112-117. https://doi.org/10.1080/00222937308696775

Cokendolpher J.C. \& Peek M.L. 1991. Horatio C. Wood (1841-1920) and his contributions to Arachnology. Revue arachnologique 9 (8): 89-101.

Coronato-Ribeiro A. \& Pinto-da-Rocha R. 2017. Taxonomic revision and cladistic analysis of the genus Metalibitia Roewer, 1912 (Opiliones, Cosmetidae, Cosmetinae). Zootaxa 4291 (2): 201-242.

https://doi.org/10.11646/zootaxa.4291.2.1

García A.F. \& Kury A.B. 2017. Taxonomic revision of the Andean harvestman genus Rhaucus Simon, 1879 (Arachnida, Opiliones, Cosmetidae). Zootaxa 4338 (3): 401-440.

https://doi.org/10.11646/zootaxa.4338.3.1

Gervais P. 1844. Acères Phrynéides, Scorpionides, Solpugides, Phalangides et Acarides; Dicères Épizoïques, Aphaniptères et Thysanoures. In: Walckenaer C.A. (ed.) Histoire naturelle des Insectes aptères, Tome 3: 94-131. Librairie Encyclopédique de Roret, Paris.

González-Sponga M.A. 1992. Arácnidos de Venezuela. Opiliones Laniatores II. Familia Cosmetidae. Academia de Ciencias Físicas, Matemáticas y Naturales, Caracas.

González-Sponga M.A. 1996. Arácnidos de Venezuela. Un nuevo género y una nueva especie de la familia Cosmetidae del Parque Nacional "Serranía de la Neblina", Edo. Amazonas (Opiliones). Boletín de la Academia de Ciencias, Matemáticas y Naturales 53: 97-107.

González-Sponga M.A. 1998a. Arácnidos de Venezuela. Dos nuevos géneros y cuatro nuevas especies de Opiliones Laniatores del Tepui Guaiquinima y del Parque Nacional Canaima (Phalangodidae: Cosmetidae). Memoria Sociedad de Ciencias Naturales La Salle 57 (148): 3-16.

González-Sponga M.A. 1998b. Arácnidos de Venezuela. Un nuevo genero y cinco nuevas especies de Opiliones Laniatores (Cosmetidae). Acta Biologica Venezuelica 18 (4): 1-16.

Goodnight C.J. \& Goodnight M.L. 1953. The opilionid fauna of Chiapas, Mexico, and adjacent areas (Arachnoidea, Opiliones). American Museum Novitates 1610: 1-81. 
Kästner A. 1937. Chelicerata. 7. Ordnung der Arachnida: Opiliones Sundeval = Weberknechte. In: Kukenthal W. \& Krumbach T. (eds) Handbuch der Zoologie vol. 3 no. 2: 300-393. Berlin \& Leipzig, Walter de Gruyte.

Krell F.T. \& Marshall S.A. 2017. New species described from photographs: yes? no? sometimes? a fierce debate and a new declaration of the ICZN. Insect Systematics and Diversity 1: 3-19. https://doi.org/10.1093/isd/ixx004

Kury A.B. 2003. Annotated catalogue of the Laniatores of the New World (Arachnida, Opiliones). Revista Ibérica de Aracnología vol. especial monográfico 1: 1-337.

Kury A.B. 2012. A new genus of Cranaidae from Ecuador (Opiliones: Laniatores). Zootaxa 3314: 3144. https://doi.org/10.11646/zootaxa.3314.1.3

Kury A.B. \& Barros C.M. 2014. A new genus and eight new species of Amazonian cosmetines (Opiliones, Laniatores, Cosmetidae). Zoological Studies 53: 1-46. https://doi.org/10.1186/s40555-014-0024-4

Kury A. \& Medrano M. 2016. Review of terminology for the outline of dorsal scutum in Laniatores (Arachnida, Opiliones). Zootaxa 4097 (1): 130-134. https://doi.org/10.11646/zootaxa.4097.1.9

Kury A.B. \& Medrano M. 2018. A whiter shade of pale: anchoring the name Paecilaema C. L. Koch, 1839 onto a neotype (Opiliones, Cosmetidae). Zootaxa 4521 (2): 191-219.

https://doi.org/10.11646/zootaxa.4521.2.3

Kury A.B. \& Orrico V.G.D. 2006. A new species of Lacronia Strand, 1942 from the highlands of Rio de Janeiro (Opiliones, Gonyleptidae, Pachylinae). Revista Ibérica de Aracnología 13: 147-153.

Kury A.B. \& Villarreal M.O. 2015. The prickly blade mapped: establishing homologies and a chaetotaxy for macrosetae of penis ventral plate in Gonyleptoidea (Arachnida, Opiliones, Laniatores). Zoological Journal of the Linnean Society 174 (1): 1-46. https://doi.org/10.1111/zoj.12225

Kury A.B, Giupponi A.P.L \& Mendes A.C. 2018. Immolation of Museu Nacional, Rio de Janeiro unforgettable fire and irreplaceable loss. Journal of Arachnology 46 (3): 556-558.

https://doi.org/10.1636/JoA-S-18-094.1

Martens J. 1978. Spinnentiere, Arachnida: Weberknechte, Opiliones. Die Tierwelt Deutschlands 64. G. Fischer Verlag, Jena.

Medrano M. \& Kury A.B. 2016. Characterization of Platymessa with redescription of the type species and a new generic synonymy (Arachnida, Opiliones, Cosmetidae). Zootaxa 4085 (1): 52-62.

https://doi.org/10.11646/zootaxa.4085.1.2

Medrano M. \& Kury A.B. 2017. Taxonomic revision of the Andean genus Eulibitia Roewer, 1912 (Arachnida, Opiliones, Cosmetidae), with the description of five new species. European Journal of Taxonomy 357: 1-55. https://doi.org/10.5852/ejt.2017.357

Medrano M.A. \& Kury A.B. 2018. Relationships and cladistic analysis of Roquettea with description of two new species and notes about evolution of stylus in Cosmetidae (Opiliones, Grassatores). Invertebrate Systematics 32: 1206-1233. https://doi.org/10.1071/IS18013

Medrano M., Villarreal O. \& Kury A.B. 2019. Review of Neocynorta Roewer, 1915 with two new generic synonymies (Opiliones, Gonyleptoidea, Cosmetidae). Journal of Natural History 53 (11-12): 677-704. https://doi.org/10.1080/00222933.2019.1606357

Mello-Leitão C.F de 1923. Opiliones Laniatores do Brasil. Archivos do Museu Nacional 24: 107-197.

Mello-Leitão C.F de 1926. Notas sobre Opiliones Laniatores sul-americanos. Revista do Museu Paulista 14: 327-383. 
Mello-Leitão C.F. de 1932. Opiliões do Brasil. Revista do Museu Paulista 17 (2): 1-505.

Mello-Leitão C.F. de 1933. Notas sobre os opiliões do Brasil descritos na obra póstuma de Sörensen: "Descriptiones Laniatorum". Boletim do Museu Nacional 9 (1): 99-114.

Monteiro Y.F. \& Pinto-Da-Rocha R. 2015. Revision of the genus Ferkeria Roewer, 1947, with the description of a new species (Opiliones: Laniatores: Cosmetidae). Zootaxa 4006 (2): 361-373.

https://doi.org/10.11646/zootaxa.4006.2.7

Myers N., Mittermeier R.A., Mittermeier C.G., Fonseca G.A.B. \& Kent J. 2000. Biodiversity hotspots for conservation priorities. Nature 403: 853-858. https://doi.org/10.1038/35002501

Olivier G.A. 1792. Catalogue des insectes envoyés de Cayenne, à la Société d'Histoire Naturelle de Paris, par M. Le Blond. Actes de la Société d'Histoire Naturelle de Paris 1: 120-125.

Pinto-da-Rocha R. \& Hara M.R. 2011. Redescription of Platygyndes Roewer 1943, a false Gonyleptidae, (Arachnida, Opiliones, Cosmetidae). ZooKeys 143: 1-12. https://doi.org/10.3897/zookeys.143.1916

Roewer C.F. 1912. Die Familie der Cosmetiden Opiliones-Laniatores. Archiv für Naturgeschichte Abteilung A 78 (10): 1-122.

Roewer C.F. 1923. Die Weberknechte der Erde. Systematische Bearbeitung der bisher bekannten Opiliones. Gustav Fischer, Jena.

Roewer C.F. 1928. Weitere Weberknechte II. (2. Ergänzung der Weberknechte der Erde, 1923). Abhandlungen des Naturwissenschaftlichen Vereins zu Bremen, 26 (3): 527-632.

Roewer C.F. 1947. Diagnosen neuer Gattungen und Arten der Opiliones Laniatores (Arachn.) aus C.F. Roewer's Sammlung im Senckenberg-Museum. 1. Cosmetidae. [Weitere Weberknechte XII]. Senckenbergiana 28 (1/3): 7-57.

Simon E. 1879. Essai d'une classification des Opiliones Mecostethi. Remarques synonymiques et descriptions d'espèces nouvelles. Première partie. Annales de la Société entomologique de Belgique 22: $183-241$.

Simon E. 1880. Premier supplément au travail intitulé essai d'une classification des Opiliones Mecostethi, etc. (première partie). Comptes rendus des séances de la Société entomologique de Belgique 1880: 100-103.

Soares H.E.M. 1970. Novas espécies de opiliões da Região Amazônica (Opiliones, Cosmetidae, Gonyleptidae, Phalangiidae, Stygnidae). Revista Brasileira de Biologia 30 (3): 323-338.

Sørensen W.E. 1932. Descriptiones Laniatorum (Arachnidorum Opilionum Subordinis). Opus posthumum recognovit et edidit Kai L. Henriksen. Det Kongelige Danske Videnskabernes Selskabs Skrifter 3: 197-422.

Wood Jr. H.C. 1869. On the Phalangia and Pedipalpi collected by Professor Orton in Western South America, with the description of new African species. Transactions of the American Philosophical Society 13: 435-442. https://doi.org/10.5962/bhl.title.4003

Manuscript received: 6 September 2019

Manuscript accepted: 16 March 2019

Published on: 24 April 2020

Topic editor: Rudy Jocqué

Desk editor: Pepe Fernández 
Printed versions of all papers are also deposited in the libraries of the institutes that are members of the EJT consortium: Muséum national d'histoire naturelle, Paris, France; Meise Botanic Garden, Belgium; Royal Museum for Central Africa, Tervuren, Belgium; Royal Belgian Institute of Natural Sciences, Brussels, Belgium; Natural History Museum of Denmark, Copenhagen, Denmark; Naturalis Biodiversity Center, Leiden, the Netherlands; Museo Nacional de Ciencias Naturales-CSIC, Madrid, Spain; Real Jardín Botánico de Madrid CSIC, Spain; Zoological Research Museum Alexander Koenig, Bonn, Germany; National Museum, Prague, Czech Republic. 